\title{
Biophysical and sociocultural factors underlying spatial trade-offs of ecosystem services in semiarid watersheds
}

\author{
$\underline{\text { Marina García-Llorente }}^{1,2}, \underline{\text { Irene Iniesta-Arandia }}^{2}, \underline{\text { Bárbara A. Willaarts }}^{3}, \underline{\text { Paula A. Harrison }}^{4}, \underline{\text { Pam Berry }}^{4}, \underline{\text { María del Mar Bayo }}^{5}$, \\ Antonio J. Castro $^{6,7}$, Carlos Montes $^{2}$ and Berta Martín-López ${ }^{2,4}$
}

\begin{abstract}
Biophysical and social systems are linked to form social-ecological systems whose sustainability depends on their capacity to absorb uncertainty and cope with disturbances. In this study, we explored the key biophysical and socio-cultural factors underlying ecosystem service supply in two semiarid watersheds of southern Spain. These included variables associated with the role that freshwater flows and biodiversity play in securing the system's capacity to sustain essential ecosystem services and their relationship with social demand for services, local water governance, and land-use intensification. Our results reveal the importance of considering the invisible dimensions of water and biodiversity, i.e. green freshwater flows and trait-based indicators, because of their relevance to the supply of ecosystem services. Furthermore, they uncover the importance of traditional irrigation canals, a local water governance system, in maintaining the ecosystems' capacity to supply services. The study also highlights the complex trade-offs that occur because of the spatial mismatch between ecosystem service supply (upstream) and ecosystem service demand (downstream) in watersheds. Finally, we found that land-use intensification generally resulted in losses of the biophysical factors that underpin the supply of some ecosystem services, increases in social demand for less diversified services, and the abandonment of local governance practices. Attempts to manage social-ecological systems toward sustainability at the local scale should identify the key biophysical and socio-cultural factors that are essential for maintaining ecosystem services and should recognize existing interrelationships between them. Land-use management should also take into account ecosystem service trade-offs and the consequences resulting from land-use intensification.
\end{abstract}

Key Words: demand; freshwater flow; interaction; irrigation community; land-use intensification; social-ecological system; social preference; spatial pattern; trait-based indicator

\section{INTRODUCTION}

It is widely recognized that ecosystems directly or indirectly contribute to human well-being through the supply of vital ecosystem services (MA 2005, Díaz et al. 2006). The Millennium Ecosystem Assessment (http://millenniumassessment.org/en/ index.aspx), the Economics of Ecosystems \& Biodiversity (http:// www.teebweb.org/), and the Intergovernmental Platform on Biodiversity \& Ecosystem Services (http://www.ipbes.net) have brought the ecosystem services concept into broader environmental planning and policy arenas. This has been possible because of the development of new conceptual and analytical frameworks that analyze the complex relationships between biophysical and social systems (Ban et al. 2013). These frameworks recognize that biophysical and social systems are interdependent and form social-ecological systems (SESs; Liu et al. 2007, Ostrom 2009). Ostrom $(2007,2009)$ developed a general framework to explore sustainability through the analysis of interdependencies and complex linkages in SESs. This study adapts Ostrom's framework to empirically conceptualize two Mediterranean semiarid watersheds as SESs (Fig. 1). Under this framework, different subsystems are identified: the biophysical system and its related ecological processes (i.e., the freshwater flows and biodiversity that underlie the supply of ecosystem services in semiarid watersheds), the supplied ecosystem services, the system's users (i.e., the beneficiaries who generate ecosystem service demand), and the governance system (i.e., local water governance). All are jointly affected by different drivers of change (Fig. 1).

This framework is a useful tool for assessing associations, i.e., trade-offs or synergies, between ecosystem services while also assessing interactions between the factors that generate and influence the provision of ecosystem services. For example, it allows the study of (1) supply-supply trade-offs where the provision of one or several services compromises the provision of others and supply-supply synergies where ecosystem services are provided concurrently; (2) demand-demand trade-offs between beneficiaries where the demand for one or various ecosystem services negatively affects the interest or needs of other stakeholders and demand-demand synergies where stakeholders share a common interest; and (3) supply-demand trade-offs/ synergies where there is a temporal or spatial mismatch/match between ecosystem service supply and the derived social demand (Mouchet et al. 2014).

Different authors have remarked on the necessity of conducting research focused on ecosystem service associations to properly implement the concept into real conservation and management actions (Howe et al. 2014). It can help to identify and promote management strategies that are able to enhance a flow of ecosystem services simultaneously (Raudsepp-Hearne et al.

${ }^{1}$ Department of Applied Research and Agricultural Extension, Madrid Institute for Rural, Agricultural and Food Research and Development (IMIDRA), ${ }^{2}$ Social-Ecological Systems Laboratory, Department of Ecology, Universidad Autónoma de Madrid, ${ }^{3}$ Centro de Estudios e Investigación para la Gestión de de Riesgos Agrarios y Medioambientales, Universidad Politécnica de Madrid, ${ }^{4}$ Environmental Change Institute, University of Oxford, ${ }^{5}$ Laboratorio Analítico Bioclínico, Parque Científico Tecnológico de Almería, ${ }^{6}$ Andalusian Center for the Assessment and Monitoring of Global Change, Department of Biology and Geology, Universidad de Almería, ${ }^{7}$ Department of Biological Sciences, Idaho State University 
2010); highlight the consequences of difficult management decisions (McShane et al. 2011); and improve understand of the functioning of ecological processes that are important for service supply and the drivers of change that affect them to avoid unexpected changes (Bennett et al. 2009). However, the majority of studies to date have focused on single services (Seppelt et al. 2011, Mitchell et al. 2013) or one-to-one relationships; studies considering several ecosystem services are urgently required (Bennett et al. 2009, Howe et al. 2014). Moreover, although knowledge on the role of biodiversity for the supply of ecosystem services is improving (Cardinale et al. 2012), few empirical studies have focused on understanding the social-ecological processes that underpin services (Bennett et al. 2009, Lavorel and Grigulis 2012) and the effects of governance decisions and environmental change on their supply (Harrison et al. 2014).

Fig. 1. General framework for analyzing sustainability in socialecological systems (SESs). This study adapts Ostrom's framework to empirically conceptualize two Mediterranean semiarid watersheds as SESs (Fig. 2). Under this framework, different subsystems are identified: the biophysical system with capacity to supply ecosystem services (i.e., freshwater flows and biodiversity that underlie the supply of ecosystem services in semiarid watersheds), the supplied ecosystem services, the system's users (i.e., the beneficiaries who generate ecosystem service demand), and the governance system (i.e. local water governance), which are all jointly affected by different drivers of change (i.e., land-use intensification). Gray arrows with two arrowheads represent the interaction between the different subsystems in terms of interdependencies and trade-offs. Methodological steps (Ms) followed in the study are also represented. Adapted from Ostrom $(2007,2009)$ for the study case.

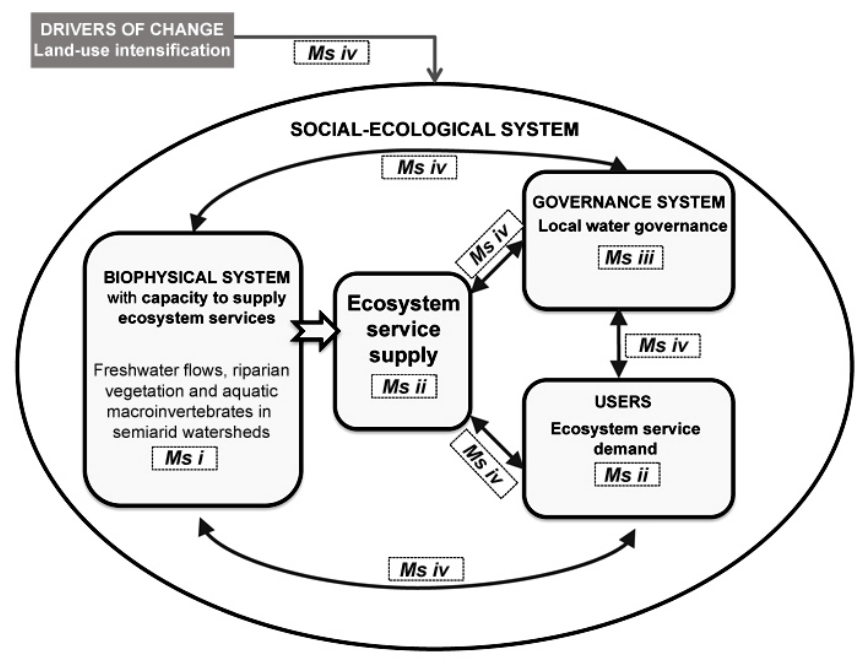

Semiarid systems in the Mediterranean Basin have been identified as areas where water resources and biodiversity have significantly deteriorated (García-Ruiz et al. 2011, Lorenzo-Lacruz et al. 2012), with important consequences for ecosystem service supply and human well-being (Safriel and Adeel 2005, Spanish NEA 2014). In this sense, good management of freshwater flows (runoff or blue water flow and evapotranspiration or green water flow) and biodiversity is essential for the supply of provisioning (e.g., freshwater, food for human consumption), regulating (e.g., water quality, erosion control), and cultural (e.g., local identity, recreational activities, spiritual values) services, which all contribute to human needs (Díaz et al. 2006, Brauman et al. 2007, Willaarts et al. 2012). As was found by Martín-López et al. (2012), people appreciate the ecosystem services obtained from watersheds in semiarid systems highly and manage these systems based on their knowledge and perception of the factors affecting service supply. However, different stakeholders hold different social perceptions regarding the importance of individual ecosystem services, which can result in potential trade-offs between beneficiaries. Furthermore, certain stakeholders possess higher levels of power in relation to land-use management so that their knowledge and interests drive land-use changes, with consequences in the ecosystem services supply (Iniesta-Arandia et al. 2014). During the last 60 years, land-use change in the Mediterranean has been characterized by the abandonment of farming in marginal rural areas and the intensification of agriculture in valleys and flat areas (Aznar-Sánchez et al. 2011). These strategies have contributed to local socioeconomic development, but at the same time they have also affected ecosystem service supply and the landscape configuration (VidalLegaz et al. 2013).

This study aims to identify the connections between biophysical and socio-cultural factors in two semiarid watersheds in the Mediterranean Basin to explore key factors underlying ecosystem service supply and the sustainability of SESs at the local scale. Our specific objectives were (1) to assess the relationships between biophysical and socio-cultural factors underpinning ecosystem services supply and the effect of land-use intensification as a key direct driver of change in the region and (2) to explore the spatial pattern of these interactions and the resulting spatial trade-offs in ecosystem service supply and demand along the watersheds. To address these objectives, we analyzed (see Fig. 1) the biophysical factors underpinning ecosystem services in terms of blue and green freshwater flows and variables related to riparian vegetation and aquatic macroinvertebrates; the supply of ecosystem services and their social demand, in terms of importance and use; the role of local water governance factors in ecosystem services supply and demand; and the associations among these three factors and land-use intensification. We furthermore visualized the spatial pattern of these interactions and the resulting spatial trade-offs (supply-demand).

The complexity of linkages in SESs requires approaches that are able to integrate the whole range of interactions between subsystems (Fig. 1). It also requires studies that assess trade-offs at relevant spatial scales, which will depend on where a particular service is supplied, demanded, and managed, and when trade-offs could emerge. As shown by Howe et al. (2014), many trade-offs emerge at the local scale, because stakeholder interests are usually at this scale. Thus, we made a special effort to collect primary and secondary data at the local scale to obtain reliable assessments of the key factors that generate and influence the provision of ecosystem services. This also enabled the interactions between these factors to be tested. In this context, the current study illustrates an application of social-ecological, place-based research as it contributes to the advancement of knowledge on the associations between biophysical and socio-cultural factors 
Fig. 2. Maps showing (A) Spain, (B) watersheds in Andalusia, (C) biological sample points, and (D) social sample points in the Nacimiento and Adra watersheds.
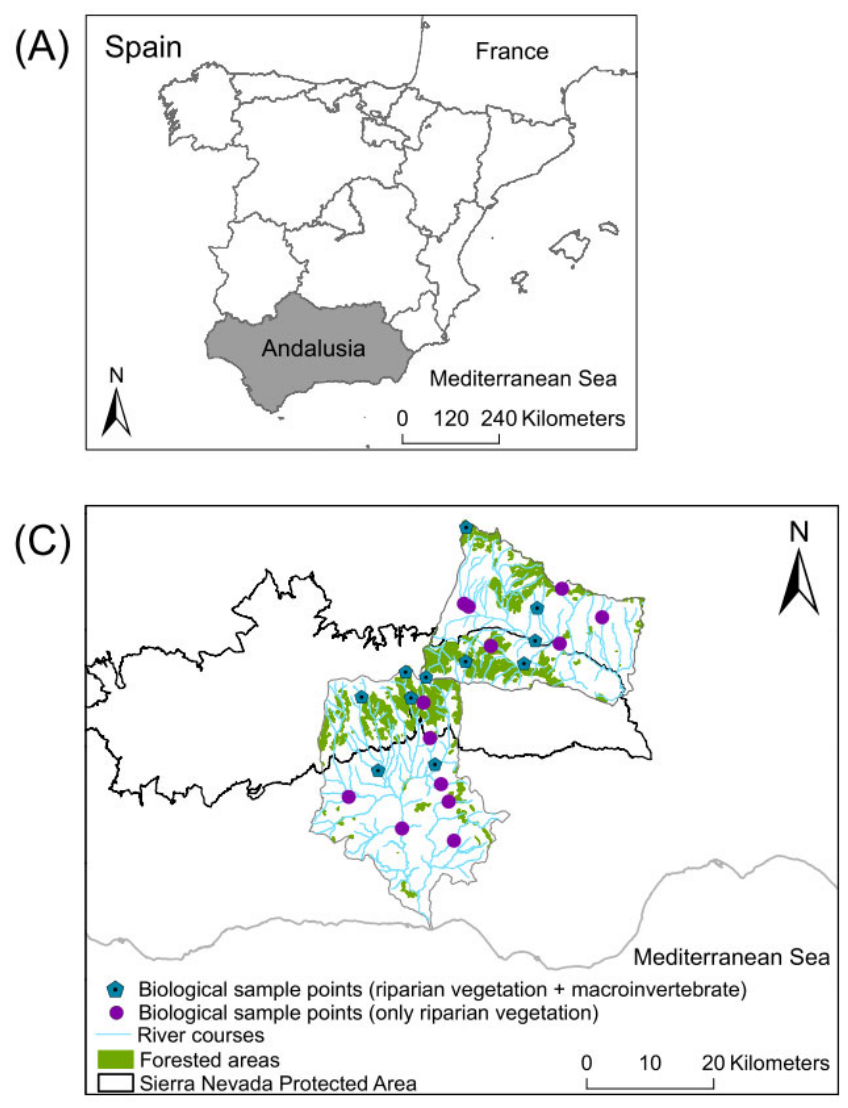

that drive ecosystem service interactions in the European semiarid region. Therefore, we seek to draw attention to the importance of interdisciplinary research at the local scale for understanding the complexities behind ecosystem service interactions and, in turn, to contribute to the Programme on Ecosystem Change and Society (http://www.pecs-science.org).

\section{STUDY AREA}

We conducted this study in two semiarid watersheds, conceptualized as SESs: the Adra and the Nacimiento, both located in the Almeria and Granada provinces in southeast Spain (Fig. 2). Both watersheds are part of the so-called Andalusian Mediterranean River Basin district. The Adra watershed drains an area of $742 \mathrm{~km}^{2}$ and has a population of 55,601 inhabitants distributed across 14 municipalities. The Nacimiento watershed, a natural corridor bordered by two mountainous massifs, has a drainage area of $598 \mathrm{~km}^{2}$, has 12,305 inhabitants in 10 municipalities, and is the upper part of the Andarax watershed. The headwaters of the two watersheds are located in the Sierra Nevada Protected Area, which is the highest mountain range in the Iberian Peninsula, whereas the lowlands are characterized by having a marked Mediterranean semiarid climate. Despite sharing a common and homogeneous history that provides both watersheds with a marked agrarian character, more recent development processes, especially since the 1950s, have led to

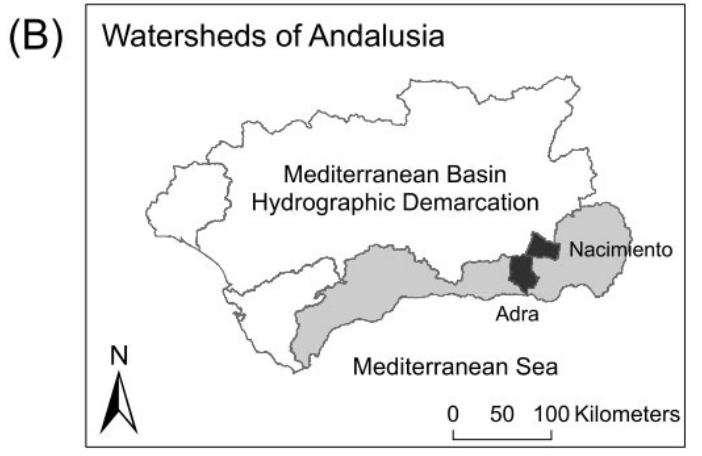

(D)

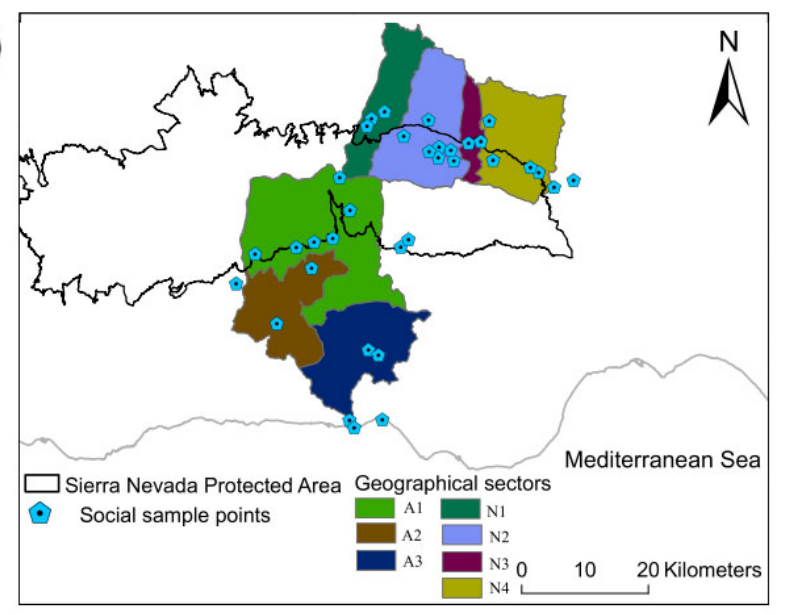

considerable differentiation of upstream and downstream regions. In general terms, the upper mountainous areas are still characterized by subsistence farming, mostly dedicated to growing olive and almond trees on terraces, and have recently experienced a strong process of depopulation. In contrast, the lower areas with milder climates (mainly in the Adra watershed) have developed competitive, intensive greenhouse horticulture (Aznar-Sánchez et al. 2011), which not only has led to the overexploitation of aquifers and water and soil pollution, but also has created several social conflicts (Sánchez-Picón et al. 2011, Quintas-Soriano et al. 2014).

In previous studies, both watersheds were divided into homogeneous geographical sectors (four in the Nacimiento watershed and three in the Adra watershed; Fig. 2) using a set of economic, demographic, social, resource-use, and land-use variables, and performing multivariate statistical analyses; see Iniesta-Arandia et al. (2011) for more details. The four geographical sectors of the Nacimiento watershed, N1, N2, N3, and N4, are arranged in a west-east gradient. N1 represents municipalities in the Granada province, which are characterized by the highest altitude (more than 1000 miles above sea level) and are mainly devoted to livestock, cereal crops, and olive and almond orchards. N2 represents the Upper Nacimiento of the Almeria province municipalities, which are dedicated to olive and almond tree orchards. N3 represents the intermediate 
Nacimiento, which is characterized by a younger population with a higher level of formal education and an economy devoted to new land-uses and service sector jobs. N4 represents the lower Nacimiento, which contains the municipalities with the oldest populations and has chronic depopulation. The three geographical sectors of the Adra watershed, A1, A2, and A3, are split in a north-south gradient. A1 represents the Upper Adra, which contains several municipalities that are protected under the Sierra Nevada Natural Protected Area and therefore have significant territory dedicated to forest landscapes and some tourism, e.g., snow tourism and hiking. A2 represents municipalities in the Contraviesa mountains, which are characterized by livestock production, almond and olive orchards, and vineyards. A3 represents the lower Adra, which is focused on intensive agriculture in greenhouse farms that supports a higher population density. This geographical zoning was taken into account in the data compilation and analysis of all the factors described in this study.

\section{METHODS}

\section{Hydrological factors}

Blue and green freshwater flows were used as key biophysical factors related to the supply of ecosystem services in watersheds. We refer to blue freshwater flow as the surface runoff or groundwater flow feeding rivers, lakes, or wetlands and to aquifers and green freshwater flow as the soil moisture evapotranspired by vegetation (see Table 1; Falkenmark and Rockström 2004). Blue water flows generate well-known ecosystem services, such as freshwater for human consumption, irrigated croplands, the maintenance of habitats for aquatic biodiversity, and aquatic recreation activities. Green water flows have been commonly associated with provisioning services such as food production because the rainfall infiltrated and stored in the soil supports the primary productivity required for agricultural activities; however, they also generate numerous regulating and cultural services (Willaarts et al. 2012). To assess the blue and green freshwater flows within each of the two watersheds, we used the ecohydrologic model BalanceMED (Willaarts et al. 2012). BalanceMED is a semideterministic model that can be used to quantify the mean hydrological flows of Mediterranean watersheds using long-time series of monthly rainfall and potential evapotranspiration. The model is spatially explicit and provides monthly outputs of both blue and green freshwater flows.

\section{Biological factors}

To quantify the effect of biodiversity on ecosystem service supply, we measured a traditional metric of diversity, the ShannonWeaver diversity (H; Shannon 1948) for riparian vegetation and aquatic macroinvertebrates (Table 1). In addition, we analyzed functional indicators because it is recognized that functional composition has the most important effect on ecosystem service supply among all components of biodiversity (Díaz et al. 2006). We measured the trait-based indicators identified in previous studies as potentially useful predictors of key ecosystem processes for ecosystem service supply, with a focus on riparian and aquatic vegetation (Díaz et al. 2007, García-Llorente et al. 2011) and aquatic macroinvertebrates (Archaimbault et al. 2010, Vandewalle et al. 2010). Both biological communities play an important role in maintaining water quality and erosion control: two main elements of the ecological functioning in semiarid environments (Armas et al. 2011, Castro et al. 2014).

Riparian and aquatic plants with complex root architecture enhance soil stability and erosion control, whereas water quality depends on nutrient retention as mediated by traits such as leaf area, growth form diversity, and decomposability (Díaz et al. 2007, De Bello et al. 2010, García-Llorente et al. 2011). Furthermore, macroinvertebrates are key indicators for assessing water quality (Cheimonopoulou et al. 2011). For example, macroinvertebrates with shedders' feeding habits have bioturbation potential to improve nutrient mobilization and water quality (De Bello et al. 2010). Even though functional traits have been previously examined (Usseglio-Polatera et al. 2000), explicit associations among traits and ecosystem services are not yet well documented for macroinvertebrates (De Bello et al. 2010). However, in this study, our intention was to focus on those traitbased indicators that have been shown to have the capacity to denote ecosystem service supply rather than on particular functional groups attached to particular services.

Different indices have been proposed to measure the functional traits of a community, but there is no consensus about which factors are most suitable (Casanoves et al. 2011). In this study, to avoid the richness effect, we used the functional dispersion index (FDis, Table 1), which is the mean distance in multidimensional trait space of individual species to the centroid of all species. It includes species abundances by shifting the position of the centroid toward the more abundant species and weighting distances of individual species by their relative abundances (Laliberté and Legendre 2010). This index is also used to measure response diversity, which is defined as the species' ability to persist in the face of environmental changes.

Riparian vegetation and macroinvertebrates were sampled at 24 points throughout both watersheds. All biological data were obtained in the spring (April 2009) to avoid possible seasonal differences in results due to the wide seasonal changes in Mediterranean rivers (Williams 2005). Sample points for biological factors are shown in Figure 2. Appendix 1 provides a description of the sample points and the list of traits and their subdivision into attributes used to calculate the functional dispersion index.

\section{Ecosystem services: supply and social demand}

We considered the ecosystem service supply and the social demand for ecosystem services in terms of importance or use. The selection of ecosystem services was based on the key services in the study area, the need to cover all categories of ecosystem services, and the availability of data in accessible data sources, such as official statistics. Overall, we compiled information on provisioning (food from traditional agriculture and freshwater), regulating (erosion control and water quality), and cultural (ecotourism) services.

Food from traditional agriculture, freshwater, and erosion control have been found to be critical in the area because they were perceived as both important for social well-being and vulnerable to loss or degradation (Iniesta-Arandia et al. 2014). These services are highly related to the agrarian and semiarid characteriztics of the study area, which are directly affected by the land-use change taking place, i.e., land-use intensification near the coast and 
Table 1. Summary of biophysical (hydrological and biological), ecosystem services (supply and social demand), local water governance, and land-use intensification factors and specific variables used to analyze social-ecological systems' interactions in the Adra and Nacimiento watersheds. SIMA indicates Andalusian Multi-territorial Information System; CAPMA, Regional Ministry of Agriculture, Fisheries and Environment of the Government of Andalusia. Acquisition years of data compiled from SIMA correspond to the last available year with information.

\begin{tabular}{|c|c|c|c|c|}
\hline Variable name & Code & Attributes & Type & Source \\
\hline \multicolumn{5}{|l|}{ Hydrological factors } \\
\hline Blue water flow & BWF & Water runoff in aquifers, lakes, rivers, wetlands, etc. $\left(\mathrm{m}^{3} /\right.$ ha year) & Continuous & Secondary data \\
\hline Green water flow & GWF & $\begin{array}{l}\text { Water availability in the root zone; water stored and recycled through plants } \\
\text { and soils }\left(\mathrm{m}^{3} / \text { ha year) }\right.\end{array}$ & Continuous & Secondary data \\
\hline \multicolumn{5}{|l|}{ Biological factors } \\
\hline $\begin{array}{l}\text { Shannon-Weaver } \\
\text { Index }\end{array}$ & $\mathrm{H}$ & Diversity index usually used to measure biodiversity $^{\dagger}$ & Continuous & Primary data \\
\hline Functional dispersion & FDis & $\begin{array}{l}\text { Mean distance in multidimensional trait space of individual species to the } \\
\text { centroid of all species including species abundances by shifting the position of } \\
\text { the centroid toward the more abundant species and weighting distances of } \\
\text { individual species by their relative abundances }\end{array}$ & Continuous & Primary data \\
\hline \multicolumn{5}{|c|}{ 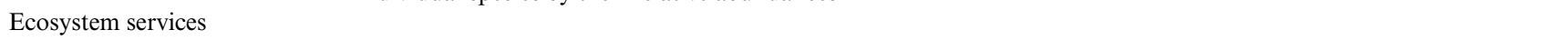 } \\
\hline \multicolumn{5}{|l|}{ Ecosystem service supply } \\
\hline Traditional agriculture & TA & $\begin{array}{l}\text { Food from crops of olive tree, almond tree, vine, cereal, fruit orchard. } \\
\text { Expressed in \% of the surface (ha) occupied by agriculture (excluding } \\
\text { greenhouses) in } 2007 / \text { sector surface (ha) }\end{array}$ & Continuous & $\begin{array}{l}\text { Secondary data } \\
\text { (SIMA) }\end{array}$ \\
\hline Freshwater & BWF & $\begin{array}{l}\text { Water for agriculture and human consumption. It was interpreted following the } \\
\text { blue water figures obtained in the hydrological factors. Water runoff in } \\
\text { aquifers, lakes, rivers, wetlands, etc. ( } \mathrm{m}^{3} / \text { ha year) }\end{array}$ & Continuous & Secondary data \\
\hline Water quality & WQ & $\begin{array}{l}\text { Water conditions of purification and oxygenation by plants and } \\
\text { macroinvertebrates. Iberian Biological Monitoring Working Party (IBMWP) as } \\
\text { biological indicator of water quality }\end{array}$ & Continuous & Primary data \\
\hline Erosion control & ERO & $\begin{array}{l}\text { Mediation of mass flows like the attenuation of runoff rates by plants. Surface } \\
\text { with low erosion in } \% \text { ( } 2006 \text { year) }\end{array}$ & Continuous & $\begin{array}{l}\text { Secondary data } \\
\text { (SIMA) }\end{array}$ \\
\hline Ecotourism & ECOT & $\begin{array}{l}\text { Physical and experiential interactions with nature though hiking or other } \\
\text { agrotourism activities. Number }(\mathrm{N}) \text { of bedroom places in rural establishments } \\
\text { (2013 year)/sector surface (ha) }\end{array}$ & Continuous & $\begin{array}{l}\text { Secondary data } \\
\text { (SIMA) }\end{array}$ \\
\hline \multicolumn{5}{|l|}{ Ecosystem service demand } \\
\hline $\begin{array}{l}\text { Main ecosystem } \\
\text { services }\end{array}$ & - & $\begin{array}{l}\text { Ecosystem services considered important for human well-being by more than } \\
20 \% \text { of respondents in the questionnaires }\end{array}$ & Continuous & Primary data \\
\hline Traditional agriculture & TAI & $\begin{array}{l}\% \text { of respondents considering traditional agriculture as important for human } \\
\text { well-being }\end{array}$ & Continuous & Primary data \\
\hline \multirow[t]{2}{*}{ Freshwater } & FWI & $\%$ of respondents considering freshwater as important for human well-being & Continuous & Primary data \\
\hline & FWC & Freshwater for human consumption and agriculture $\left(\mathrm{m}^{3} /\right.$ ha year) for 2010 year & Continuous & $\begin{array}{l}\text { Secondary data } \\
\text { (CAPMA 2010, } \\
\text { Martínez-Rodríguez } \\
\text { 2011) }\end{array}$ \\
\hline Water quality & WQI & $\%$ of respondents considering water quality as important for human well-being & Continuous & Primary data \\
\hline Erosion control & EROI & $\%$ of respondents considering erosion as important for human well-being & Continuous & Primary data \\
\hline Ecotourism & ECOTI & $\%$ of respondents considering ecotourism as important for human well-being & Continuous & Primary data \\
\hline \multicolumn{5}{|c|}{ Local water governance factors } \\
\hline $\begin{array}{l}\text { Conservation status of } \\
\text { acequias }\end{array}$ & Aceq1 & $\begin{array}{l}3=\text { very good/good conservation status, } 2=\text { regular conservation status, } 1= \\
\text { deteriorated/abandoned }\end{array}$ & Categorical & $\begin{array}{l}\text { Secondary data } \\
\text { (Sierra Nevada } \\
\text { Acequias Inventory } \\
\text { and Andalusian } \\
\text { inventory and } \\
\text { characterization of } \\
\text { irrigated lands) }\end{array}$ \\
\hline $\begin{array}{l}\text { Number of traditional } \\
\text { irrigation } \\
\text { communities }\end{array}$ & Aceq2 & $\begin{array}{l}\text { Mean of the number of irrigation communities/number of municipalities using } \\
\text { freshwater for traditional crops }\end{array}$ & Categorical & $\begin{array}{l}\text { Secondary data } \\
\text { (Andalusian } \\
\text { inventory and } \\
\text { characterization of } \\
\text { irrigated lands) }\end{array}$ \\
\hline \multicolumn{5}{|l|}{ Land-use intensification } \\
\hline Intensification & INT & $\%$ of surface with greenhouses or urbanisation (2010 year) & Continuous & $\begin{array}{l}\text { Secondary data } \\
\text { (SIMA) }\end{array}$ \\
\hline
\end{tabular}

\footnotetext{
Shannon 1948

${ }^{\ddagger}$ Laliberté and Legendre 2010
} 
abandonment in the mountains (Castro et al. 2014, QuintasSoriano et al. 2014). Both selected regulating services are also important in the context of water constraints and relief impediments, because water quality and erosion control act as intermediate services to the supply of provisioning ones, i.e., freshwater and food from agriculture. Finally, previous studies in the semiarid region of Spain have highlighted the important role of ecotourism and recreational activities in local communities, in terms of both welfare and well-being (García-Llorente et al. 2012).

The data about the supply of food from traditional agriculture, erosion control, and ecotourism were obtained from the Andalusian Multi-territorial Information System (http://www. juntadeandalucia.es/institutodeestadisticaycartografia/sima/index. $\underline{\mathrm{htm}}$ ), using as variables traditional agricultural area, the percentage of area with low erosion, and the number of bedroom places in rural hostels and hotels, respectively (Table 1). To measure the water quality of rivers and streams in both watersheds, we used macroinvertebrate data. Macroinvertebrate community structure has been commonly used for the environmental assessment of aquatic systems because of its demonstrated role as a water quality indicator (Sánchez-Montoya et al. 2010). Here, we estimated the Iberian Biological Monitoring Working Party index for water quality (Alba-Tercedor and Sanchez-Ortega 1988, Alba-Tercedor et al. 2002) because it has been widely used to assess the ecological status of surface water bodies and because it allows the actual composition of the biological community to be compared with predefined reference conditions (Munné and Prat 2009, Sánchez-Montoya et al. 2010). Quality levels (high, good, moderate, poor, and bad) were calculated based on Hydrological Planning Technical Guidance (IPH 2008), i.e. the Spanish legal instrument supporting the implementation of the EU Water Framework Directive. Finally, the freshwater supply was interpreted following the blue water figures obtained from the hydrological factors described above (Table 1).

To analyze the importance of the target ecosystem services to society, direct face-to-face questionnaire surveys were conducted in the study area between May 2009 and February 2010. The sampled population was selected randomly, with the aim of covering a wide range of ecosystem service beneficiaries, including residents in the study area, workers, and tourists. Only individuals over 18 years old were interviewed, and the total sample was made up of 381 respondents. The sampling was conducted at 34 different sampling points in the study area, including protected area offices, urban zones, city halls, agrarian offices, recreational areas, and agricultural fields (Fig. 2).

The questionnaires included a question about the ecosystem services that were highly demanded by people because of their importance for human well-being. Each respondent selected the most demanded ecosystem services from a list with examples and pictures of the ecosystem services provided by the study area (for more details, see Appendix 2). The list contained the main ecosystem services supplied in the study area, following the information collected from interviews and previous studies (MA 2005, Spanish NEA 2014). We then calculated from the questionnaires (1) which ecosystem services were highly demanded in terms of the number of respondents (expressed as a percentage) who selected them from the list (a service was considered important when it was named by more than $20 \%$ of respondents) and (2) the demand scores (expressed as a percentage) of the five selected ecosystem services (i.e., traditional agriculture, freshwater, water quality, erosion control, and ecotourism, independently of the percentage of respondents selecting them). Appendix 2 shows the questionnaire content and structure, and the list of ecosystem services presented. The question was extracted from a broader questionnaire conducted in a previous research project in the study area (for more details see Iniesta-Arandia et al. 2014). The social importance of freshwater as expressed in the questionnaires was complemented by an indicator of freshwater consumption compiled from the Regional Ministry of Agriculture, Fisheries and Environment of the Government of Andalusia (CAPMA 2010) and MartínezRodríguez (2011).

\section{Local water governance factors}

The availability of several water-related ecosystem services such as freshwater availability and water quality is linked with the use of traditional irrigation systems that use water canals and ditches because these systems manage interseasonal water availability by infiltrating and storing water in land (Pulido-Bosch and Ben Sbih 1995). To assess the importance of local water governance factors in the dynamics of SESs, we explored the role of traditional irrigation canals (hereafter called the acequia system) and their management (Meinzen-Dick 2007). The acequia system was one of the first methods used for irrigation and artificial recharging of aquifers in the Iberian Peninsula, and their use dates back to the Muslim period (Pulido-Bosch and Ben Sbih 1995). Acequias divert water away from snowmelt and the supplying river to allow gravity-fed irrigation of the downstream floodplain corridor for agriculture.

This system has been traditionally governed by local organizations that manage the distribution of water. The main role of these irrigation communities is to facilitate conflict resolution, local control, and a just and equitable distribution of water resources (Maass and Anderson 1978). Here, we analyzed water governance using the following variables: the acequias conservation status (very good/good, regular, deteriorated/ abandoned) and the number of traditional irrigation communities in each geographical sector (Table 1). These data came from the Sierra Nevada Acequias Inventory (Cano-Manuel 2000, Fernández-Escalante et al. 2006) and the Andalusian Inventory and Characterization of Irrigated Lands (Table 1).

\section{Direct driver of change: land-use intensification}

The Spanish National Ecosystem Assessment identified land-use change as the most important direct driver of change within Spanish semiarid systems (Spanish NEA 2014). In this study, we considered the impacts of a common land-use transition that has been experienced across many Spanish basins: land-use intensification. This land-use trend was quantified in each of the seven geographical sectors using the percentage of surface dedicated to greenhouses and urbanization (data from the Andalusian Multi-territorial Information System, see Table 1).

\section{Interactions between biophysical and socio-cultural factors in coupled SESs}

We used Spearman nonparametric correlation tests to determine the relationships between biophysical (i.e., hydrological and 
Table 2. Summary results of biophysical (hydrological and biological), ecosystem services (supply and social demand), local water governance, and land-use intensification factors obtained for the different geographical sectors in the Nacimiento (N) and Adra (A) watersheds. Higher values are highlighted in bold.

\begin{tabular}{|c|c|c|c|c|c|c|c|}
\hline Variable name $\dagger$ & Sector N1 & Sector N2 & Sector N3 & Sector N4 & Sector A1 & Sector A2 & Sector A3 \\
\hline \multicolumn{8}{|l|}{ Hydrological factors } \\
\hline BWF $\left(\mathrm{m}^{3} /\right.$ ha year $)$ & 1852.7 & 2498.1 & 1980.2 & 1841.1 & 2843.7 & 2592.6 & 1684.5 \\
\hline GWF (m³/ha year) & 3104.8 & 2762.9 & 2743.6 & 2399.5 & 3192.7 & 3119.3 & 2770.3 \\
\hline \multicolumn{8}{|l|}{ Biological factors } \\
\hline $\mathrm{H}$ veg & 3.50 & 3.47 & 2.78 & 3.37 & 4.20 & 3.41 & 3.21 \\
\hline FDis veg & 3.98 & 3.97 & 1.94 & 2.29 & 4.98 & 5.69 & 4.47 \\
\hline H macro & 2.41 & 3.39 & - & - & 3.21 & 1.74 & - \\
\hline FDis macro & 3.64 & 5.25 & - & - & 4.01 & 2.25 & - \\
\hline \multicolumn{8}{|c|}{ Ecosystem service supply } \\
\hline TA (\% of surface) & 22.53 & 16.91 & 12.39 & 7.92 & 9.28 & 43.34 & 0.73 \\
\hline WQ & $\begin{array}{l}88.30 \\
\text { (High) }\end{array}$ & $\begin{array}{l}66.30 \\
\text { (Good) }\end{array}$ & - & - & $\begin{array}{l}82.50 \\
\text { (High) }\end{array}$ & $\begin{array}{c}51.00 \\
\text { (Moderate) }\end{array}$ & - \\
\hline ERO $(\%)$ & 91.85 & 83.54 & 80.42 & 72.29 & 87.56 & 59.04 & 71.58 \\
\hline ECOT (N/ha) & 0.04 & 0.20 & 0.00 & 0.03 & 0.07 & 0.00 & 0.00 \\
\hline \multicolumn{8}{|c|}{ Ecosystem service demand } \\
\hline \multirow[t]{3}{*}{ Main provisioning } & $\begin{array}{l}\text { Traditional } \\
\text { agriculture }\end{array}$ & $\begin{array}{l}\text { Traditional } \\
\text { agriculture }\end{array}$ & $\begin{array}{l}\text { Traditional } \\
\text { agriculture }\end{array}$ & $\begin{array}{l}\text { Traditional } \\
\text { agriculture }\end{array}$ & $\begin{array}{l}\text { Traditional } \\
\text { agriculture }\end{array}$ & $\begin{array}{l}\text { Traditional } \\
\text { agriculture }\end{array}$ & $\begin{array}{l}\text { Intensive } \\
\text { agriculture }\end{array}$ \\
\hline & Freshwater & Freshwater & Clean energy & Clean energy & Freshwater & Livestock & Freshwater \\
\hline & $\begin{array}{l}\text { Clean energy } \\
\text { Livestock }\end{array}$ & $\begin{array}{c}\text { Clean energy } \\
\text { Timber }\end{array}$ & & Livestock & & & \\
\hline Main regulating & Air quality & $\begin{array}{l}\text { Air quality } \\
\text { Microclimate } \\
\text { regulation }\end{array}$ & Air quality & $\begin{array}{l}\text { Air quality } \\
\text { Microclimate } \\
\text { regulation }\end{array}$ & Air quality & Air quality & - \\
\hline \multirow[t]{3}{*}{ Main cultural } & Relaxation & Ecotourism & Relaxation & Relaxation & Relaxation & Relaxation & Ecotourism \\
\hline & Ecotourism & & Ecotourism & Ecotourism & Ecotourism & Ecotourism & \\
\hline & & & Env. Education & $\begin{array}{l}\text { Recreational } \\
\text { hunting }\end{array}$ & & & \\
\hline TAI (\%) & $\mathbf{5 0 . 0 0}$ & 35.71 & 26.92 & 61.11 & 31.03 & 50.00 & 19.05 \\
\hline FWI (\%) & 30.77 & 27.38 & 7.69 & 16.67 & 27.59 & 15.38 & $\mathbf{5 0 . 0 0}$ \\
\hline FWC $\left(\mathrm{m}^{3} /\right.$ ha year $)$ & 4012.85 & 2055.08 & 1281.48 & 3049.61 & 3836.89 & 3321.33 & 4955.65 \\
\hline WQI (\%) & 7.69 & 5.95 & 3.85 & 0.00 & 4.31 & 3.85 & 7.14 \\
\hline EROI (\%) & 15.38 & 13.10 & 15.38 & 5.56 & 12.93 & 3.85 & 16.67 \\
\hline ECOTI (\%) & 28.0 & 48.2 & 50.0 & 45.8 & 50.9 & 46.2 & 33.3 \\
\hline \multicolumn{8}{|c|}{ Local water governance factors } \\
\hline Aceq1 1 & 1 & 1.75 & 1.75 & 2 & 2.64 & 2.60 & 1.50 \\
\hline Aceq2 (N) & 1 & 1 & 1 & 1 & 1.50 & 1.25 & 0 \\
\hline \multicolumn{8}{|c|}{ Land-use intensification } \\
\hline INT $(\%)$ & 1.44 & 1.02 & 2.35 & 1.07 & 0.73 & 1.69 & 12.27 \\
\hline
\end{tabular}

$\dagger$ For definitions of variables, see Table 1 .

biological), ecosystem service (i.e., supply and social demand), local water governance, and land-use intensification factors $(\mathrm{n}=$ 7) across the seven geographical sectors previously identified in the Adra and Nacimiento watersheds. The correlations were mainly used to explore supply-supply associations by examining the influence of biophysical and local governance factors on the supply of the different ecosystem services.

To visualize and compare the spatial patterns of the interactions that occurred among the factors, we standardized and then transformed all data to a common scale of $0-1$, rescaling data to the maximum value observed in each sector. Finally, we created flower diagrams for the different geographical sectors in each watershed. The comparison of flower diagrams in different locations provides information on spatial supply-demand tradeoffs based on biophysical, ecosystem service (supply and social demand), and local water governance factors in the different geographical sectors in the Adra and Nacimiento watersheds, taking into account the land-use intensification. For simplification, biological factors in flower diagrams refer to only the functional dispersion index of vegetation and macroinvertebrates (i.e., FDis veg, FDis macro).

\section{RESULTS}

\section{Hydrological factors}

The pattern of blue (BWF) and green (GWF) freshwater generation follows a clear geographical gradient (maps are shown in Appendix 3). The greatest green freshwater (GWF) flows originate in the headwaters of both watersheds (sectors N1 and A1; Table 2) because these sectors receive the most rainfall and have the highest forest vegetation cover (Fig. 2). In the lower parts of the watersheds (sectors N4 and A3), rainfall and vegetation cover decrease, reducing the green freshwater (GWF). The flow of rainfall diverted to feed surface and groundwater bodies (blue freshwater flow, BWF) is also higher in the upper reaches of both watersheds (sectors $\mathrm{N} 2$ and $\mathrm{A} 1$ ). 


\section{Biological factors}

In total, 116 plant species from 40 families (the most prominent were Leguminosae, Fagaceae, Salicaceae, Labiatae, Compositae, and Gramineae) were observed across both watersheds. Although the highest values of species diversity were found in the high mountain (sector A1, H veg = 4.20), lower values were found in the lower Adra (sector A3, H veg = 3.21) and Nacimiento watersheds (sector N3, H veg = 2.78; Table 2). We found the highest values of functional dispersion in sector A2 (FDis veg = 5.69) and lower values in sector N3 (FDis veg $=1.94$, which also had lower diversity).

Macroinvertebrates from 57 genera belonging to 9 orders (Rhynchobdellida, Basommatophora, Coleoptera, Diptera, Ephemeroptera, Veneroida, Odonata, Plecoptera, and Trichoptera) were recorded. We found the highest diversity estimations of macroinvertebrates in sector $\mathrm{N} 2(\mathrm{H}$ macro $=3.39)$, followed by sector A1 $(\mathrm{H}$ macro $=3.21$, Table 2$)$, where there was a predominance of Trichoptera, Ephemeroptera, and Coleoptera families. We did not find any macroinvertebrates in sectors $\mathrm{N} 3$, $\mathrm{N} 4$, and A3, corresponding to the most downstream areas in each watershed, which had ephemeral streams with no water during the sampling period. The same tendency was observed for functional dispersion (FDis macro); the highest values were found in sectors $\mathrm{N} 2$ and $\mathrm{A} 1$ ).

\section{Ecosystem services: supply and social demand}

The supply of the ecosystem services of freshwater (in terms of BWF), water quality (WQ), and erosion control (ERO) was higher in the upper reaches of both watersheds. The surface occupied by traditional crops followed the same gradient from upper to lower watershed in both basins, with the exception of sector A1, whose area is mainly located in the protected area. Thus, in the Adra watershed the geographical sector A2 involved the largest area of traditional agriculture (TA, $43.34 \%$ of the surface) together with $\mathrm{N} 1$ (22.53\% of the surface); both sectors were also characterized by high green freshwater flows (GFW, Table 2) that maintain suitable soil moisture conditions for crops. Higher levels of ecotourism were related to the upper parts of the watersheds and the protected area.

In general, the ecosystem services with a higher social demand (named by more than $20 \%$ of respondents) included traditional agriculture, air quality, and ecotourism in almost every geographical sector (Table 2). Clean energy was one of the most important services cited in all the Nacimiento sectors, where wind farms have increased considerably in the last 10 years. In the lower Adra (sector A3), freshwater and intensive greenhouse agriculture were the principal ecosystem services demanded. In addition and particularly evident in the Adra watershed, the ecosystem service demand was more diversified in the upstream areas (sector A1), becoming more restricted in downstream areas (sector A3). In relation to the selected ecosystem services, the demand for a particular service was higher in those sectors where the service was clearly provided or where the population would like to enjoy or use this service; this is a reflection of what respondents would like to obtain from the watershed. For example, the demand for traditional agriculture (TAI) was important in those sectors traditionally associated with agricultural activities (sectors N1 or A2) and in N4, where the surface occupied by traditional crops is low but it could be a way to revitalize its population. Similarly, the social importance of erosion control(EROI) and water quality was high in those sectors with a better supply of these services (sectors $\mathrm{N} 1$ and $\mathrm{A} 1$ ) and in those sectors where these services are deteriorating, e.g., sector A3 (Table 2). Ecotourism (ECOTI) was socially important because of the existence of the protected area (sector A1). Finally, freshwater (FWI) was also demanded to a greater extent where the consumption (FWC) was higher (sector A3, Table 2).

\section{Local water governance factors}

The worst situation, in terms of acequias conservation status (Aceq 1) and the number of traditional irrigation communities (Aceq 2), was found in sector A3 of the Adra watershed, because it corresponds to the lowest watershed sector in which acequias have been replaced by pipes for intensive agriculture. In the Nacimiento watershed the situation was similar across the different geographical sectors (Table 2).

\section{Direct drivers of change: land-use intensification}

Land-use intensification (INT) levels followed a particularly strong north-south gradient in the Adra watershed, with the lower parts of the watersheds being more intensified than upper parts. In fact, $12.27 \%$ of the surface is occupied by greenhouses or urbanization in sector A3 (Table 2).

\section{Interactions between biophysical and socio-cultural factors in coupled SESs}

\section{Associations between biophysical and socio-cultural factors} underpinning ecosystem services supply

Spearman rank correlations indicated positive significant relationships between hydrological and local water governance factors (BWF-Aceq 1, BWF-Aceq 2) and between hydrological and biological factors (GWF-FDis veg; Fig. 3). Specifically, we found that blue freshwater flows (BWF) were strongly related to the conservation status of acequias (Aceq 1) and number of traditional irrigation communities (Aceq 2). Similarly, green freshwater flows (GWF) were positively related to the FDis veg. Regarding the interaction between biological factors and the supply of ecosystem services, our results showed a significant positive relation among the Shannon-Weaver diversity index of riparian vegetation $(\mathrm{H}$ veg), macroinvertebrates ( $\mathrm{H}$ macro), the functional dispersion index of macroinvertebrates (FDis macro), and the supply of water quality (WQ) as a regulating service (Fig. 3). This association is consistent with the role of these biological communities in maintaining water quality (WQ). Likewise, we found positive correlations between the riparian vegetation $(\mathrm{H}$ veg), macroinvertebrates diversity ( $\mathrm{H}$ macro), functional dispersion index of macroinvertebrates (FDis macro), and the ecotourism (ECOT) variable (Fig. 3). This indicates that suitable areas for ecotourism were associated with conserved natural environments.

Examining the relationships among ecosystem service, we found a positive correlation between both regulating services, i.e., where erosion control (ERO) was higher, water quality (WQ) was also higher (Fig. 3). Likewise, ecotourism (ECOT) and erosion control (ERO) were positively correlated. The social importance of freshwater (FWI) was correlated with the social importance of water quality (WQI), indicating that the social demand of both water-related services is located in the same geographical sectors (Fig. 3). 
Fig. 3. Interactions in coupled social-ecological systems (SESs) through biophysical (hydrological and biological), ecosystem services (supply and social demand), local water governance, and land-use intensification factors. Significant correlations in bold (statistical significance $<10 \%$ ). Values highlighted in red are negative and significant correlations; those highlighted in green are positive and significant correlations.

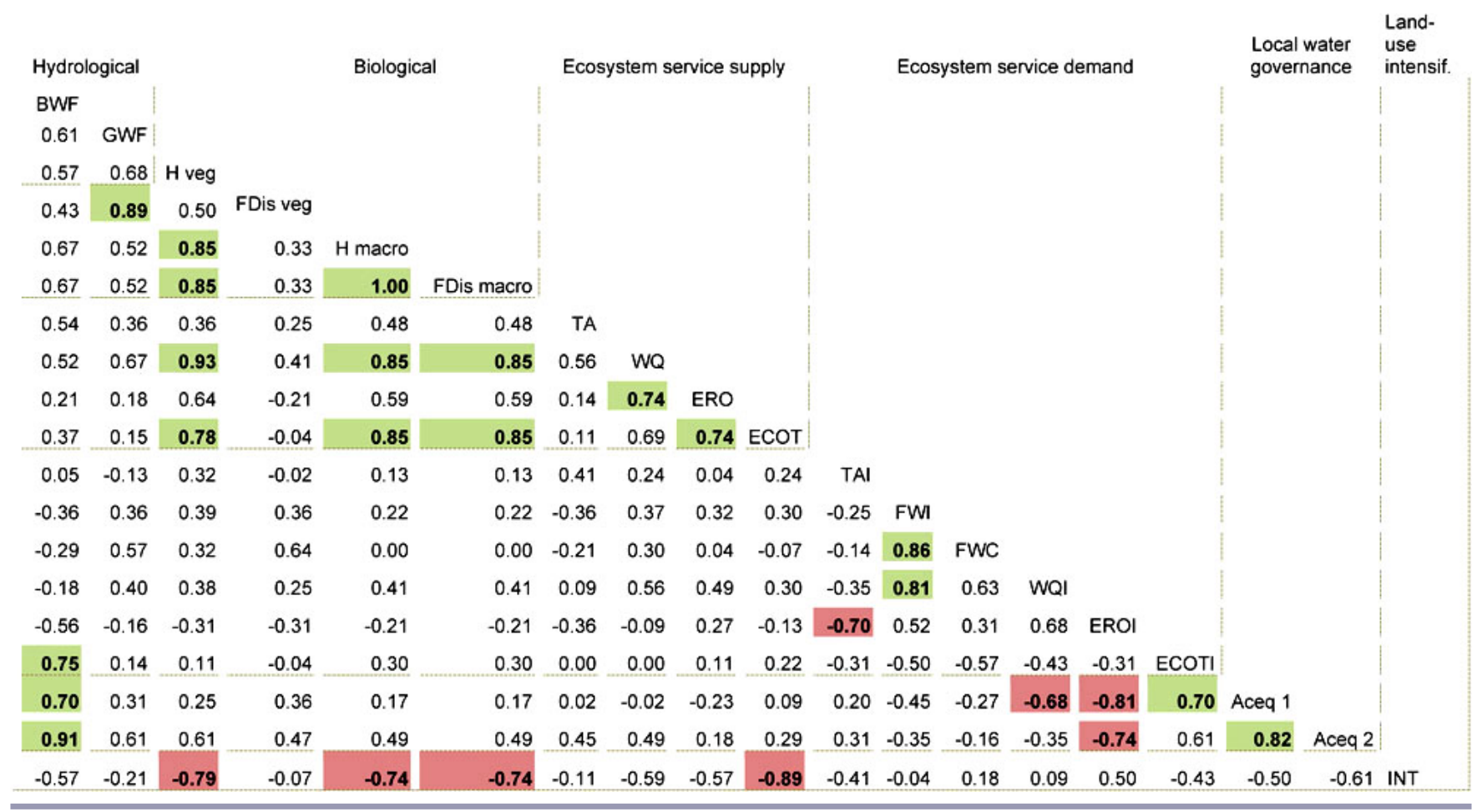

Examining ecosystem service demand, a negative relation was observed between the importance of erosion control (EROI) and traditional agriculture (TAI), indicating that in those geographical sectors where the demand for erosion control was higher there was less social importance specified for traditional agriculture. In contrast, the social demand for ecotourism (ECOTI) was higher when blue freshwater flows (BWF) and local water governance factors were higher too (Aceq 1). It is also interesting to note that when local water governance (Aceq 1, Aceq 2) was higher, there was a lower social demand for regulating services (WQI, EROI; Fig. 3). Finally, land-use intensification (INT) was significantly negatively correlated with most of the biological factors ( $\mathrm{H}$ macro, $\mathrm{H}$ veg, FDis macro) and with the supply of ecosystem services, particularly with ecotourism (Fig. 3).

Spatial patterns of the interactions: supply-demand trade-offs Clear spatial trade-offs were found for the interactions among biophysical and socio-cultural factors, and among ecosystem services supply and social demand in both watersheds; this was particularly noticeable between the upper and the lower stream of the Adra watershed (Fig. 4). In addition, when biological factors were maintained ( $\mathrm{H}$ veg, $\mathrm{H}$ macro, FDis macro), the supply of ecosystem services was also high, particularly the supply of water quality (WQ) and ecotourism (ECOT; Fig. 3). Ecological integrity in terms of the biophysical factors underpinning ecosystem services (i.e., BWF, GWF, FDis veg, FDis macro) and ecosystem services supply was maintained upstream (WQ, ERO,
ECOT); however, in the downstream areas ecosystem service demand for freshwater (FWI) and erosion control (EROI) was greater and freshwater consumption (FWC) was much higher (Fig. 4). Furthermore, downstream areas had higher land-use intensification (INT). Particularly in the Adra watershed, the geographical areas with higher levels of land-use intensification have lost the biophysical capacity to supply ecosystem services. However, they maintained a high level of freshwater consumption and social demand for ecosystem services, which were in fact degraded, especially traditional agriculture (TA), erosion control (ERO), and water quality (WQ; Fig. 4).

The overall patterns of the Nacimiento watershed followed a westeast gradient with a lower effect of land-use intensification (INT) across geographical sectors. All sectors were affected in a similar way (except sector N3, Fig. 4) because intensive agriculture is located in the valley bottoms of the mountains bordering the watershed. In the Nacimiento watershed one of the principal limitations is the groundwater resources. Freshwater flows (BWF, GWF) along the watershed decrease, with a parallel reduction in ecosystem service supply, particularly traditional agriculture (TA), water quality (WQ), and erosion control (ERO; Table 2, Fig. 4). Furthermore, users across sectors follow different strategies in terms of their ecosystem service demand. Sectors N2 and $\mathrm{N} 3$ were more focused on services related to the tertiary sector such as ecotourism, whereas $\mathrm{N} 1$ and $\mathrm{N} 4$ were interested in ecotourism (ECOTI), but especially in traditional agriculture (TA; Table 2, Fig. 4), even when the biophysical factors were not 
Fig. 4. Flower diagrams showing the relative importance of the biophysical, ecosystem services (supply and social demand), and local water governance factors in the different geographical sectors in the Nacimiento $(\mathrm{N})$ and Adra (A) watersheds taking into account the percentage of land-use intensification (expressed in terms of percentage of surface dedicated to greenhouses and urbanizations). For simplification, biological factors are only referred by the trait-based indicators (FDis veg, FDis macro), and water quality importance has not been included because it is highly correlated with freshwater importance (FWI; see Fig. 3). For definitions of variables, see Table 1.

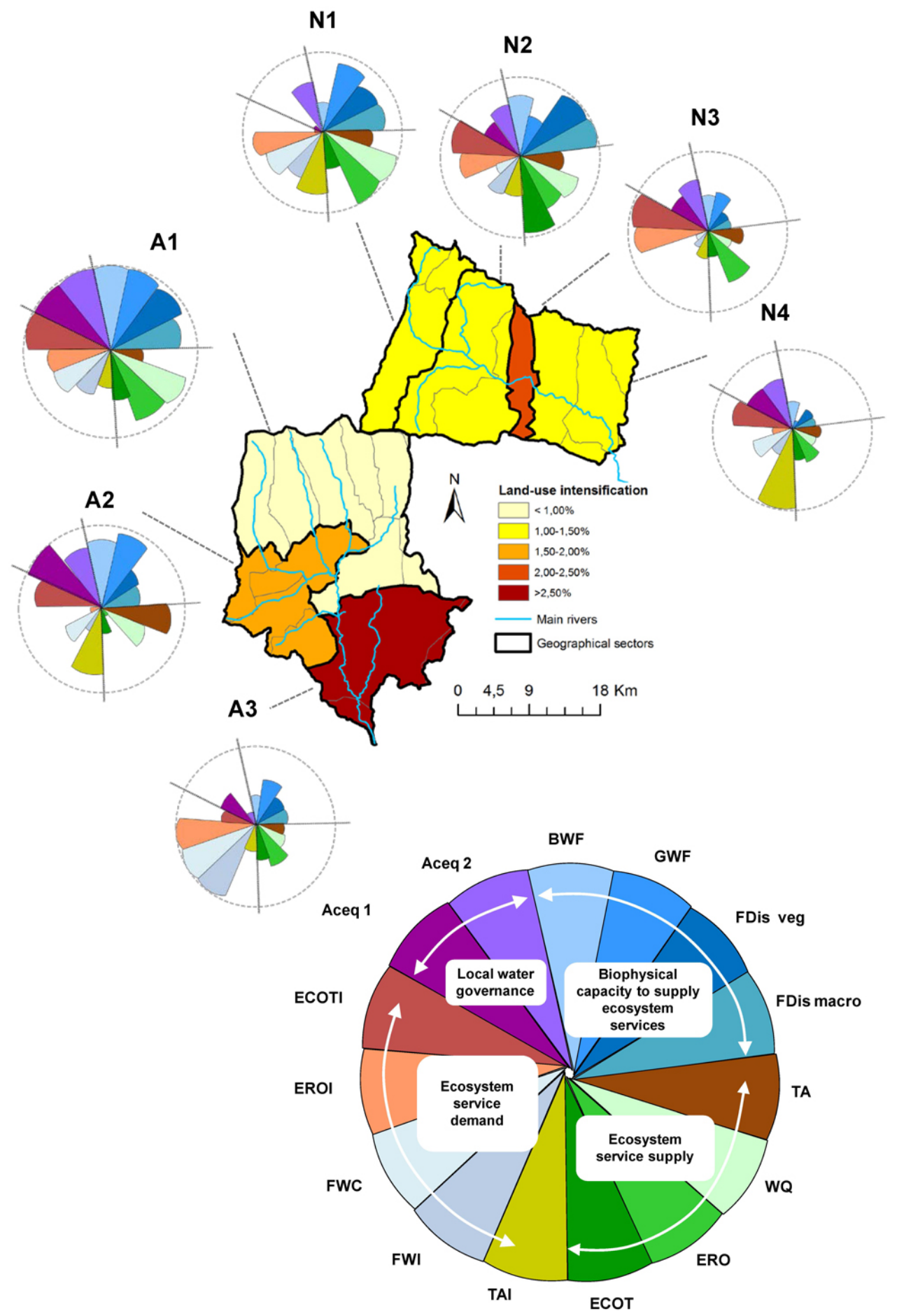


favorable (e.g. sector N4 had the lowest freshwater flows in Nacimiento watershed).

\section{DISCUSSION}

Quijas et al. (2012) highlight that plant diversity and water availability represent the key biotic and abiotic factors, underpinning the supply of ecosystem services. This statement is supported by our findings, which show that the maintenance of both blue and green freshwater flows, and biological (riparian vegetation and aquatic macroinvertebrates) trait-based indicators are essential for providing a diverse flow of ecosystem services and maintaining sustainable SESs in this semiarid system (see Fig. 4). A spatial pattern of biophysical and socio-cultural interactions was found to occur along the watersheds (from the upper to the lower watershed), resulting in spatial trade-offs of ecosystem services in relation to different levels of land-use intensification, biophysical conditions, and water governance.

Increasing the understanding of the functional consequences of drivers of change on biodiversity is critical for guaranteeing the supply of ecosystem services. Our results showed an association between more intensified areas and lower vegetation diversity; however, a clear association between land-use intensification and the functional dispersion index of vegetation was not apparent (see Fig. 3). This is supported by Laliberté et al. (2010), who observed that land-use intensification impacts on the functional attributes of plant communities and, consequently, increases vulnerability to future disturbances.

The use of trait-based indicators has been recommended in recent studies to predict the effect of different factors on ecosystem service supply (Lavorel 2013) and also to provide biodiversity information that is comparable across regions, unlike taxonomic indicators, i.e., composition of communities, that are conditioned to particular areas. However, trait-based indicators do not take into account particular species that could be the objective of conservation programs, such as threatened and endemic species (Vandewalle et al. 2010). In addition, current information on explicit associations between traits and ecosystem services is still not well documented for many taxonomic groups (Lavorel 2013). Thus, there is a need to use complementary approaches, such as species diversity metrics (Vandewalle et al. 2010). In this study, the selected biological factors were based on traditional diversity metrics (Shannon-Weaver index) and trait-based indicators of riparian vegetation and aquatic macroinvertebrates.

Intensive agriculture has been shown to disturb the ecological integrity of wetlands in semiarid Spain (Ortega et al. 2004). More intensified parts of our study areas, particularly in the low Adra, sector A3, were characterized by the lowest values for hydrological and biological factors (Fig. 4). In the lower Adra (sector A3), intensive horticulture experienced a boom beginning in the $1970 \mathrm{~s}$ (Sánchez-Picón et al. 2011). Within the last few decades, the area devoted to horticulture has increased from 3000 ha in 1975 to 27,000 ha in 2008, making Almeria the Spanish province with the largest area of greenhouses in the Mediterranean basin (AznarSánchez et al. 2011). As expected, increased water demand has been essential for this agricultural intensification (Downward and Taylor 2007, Quintas-Soriano et al. 2014), and as shown in our findings, sector A3 had the highest percentage of respondents demanding freshwater and water quality, and also the highest figures for water consumption (Table 2). In this sense, the Adra watershed could be seen as a classical spatial trade-off example, in which upstream users maintain the ecological integrity while downstream users demand ecosystem services (Maass et al. 2005, Palomo et al. 2013). According to our results, biological and hydrological factors were higher in the upper areas of the watershed, whereas the pressures and the ecosystem service demand were more intense in lower areas (Fig. 4).

This spatial mismatch in pattern is related to an ecosystem service trade-off management decision that provisioning services are preferred, prioritizing the short-term needs of society (Rodríguez et al. 2006). Similar results were found by Butler et al. (2013), who observed that different land-use management options generated trade-offs between promoting food production and water quality regulation in an Australian catchment. Land-use change motivated by economic gains and market services, such as intensive agriculture, also needs to consider the diversity of other ecosystem services and their associated values (Bateman et al. 2013). Changing the focus of agricultural management from the maximization of food production to the production of food combined with other ecosystem services could help increase social-ecological resilience (Gordon et al. 2010) and the viability of rural areas through the diversification of the services provided (Power 2010, Di Iacovo et al. 2014). We found that land-use intensification, focused on the overexploitation of one unique provisioning ecosystem service (intensive agriculture), has increased the economic growth in the region (Aznar-Sánchez et al. 2011). However, it has also resulted in (1) losses of the biophysical factors responsible for the supply of other ecosystem services, (2) the social demand for ecosystem services becoming more intensive and less diversified, and (3) the abandonment of traditional and local governance practices that influence social capital and the maintenance of other ecosystem services.

In the Nacimiento watershed, land-use intensification had a lower impact on ecosystem service trade-offs because it does not follow the classical upstream-downstream model; all sectors are similarly affected by intensive agriculture. The main drivers of change are demographic (aging and depopulation), gender change (masculinization of their populations), and land-use abandonment (Iniesta-Arandia et al. 2014). As mentioned, this watershed suffers from water supply limitations downstream because of its semiarid status and erosion problems related to the mountain topography. In this watershed, the traditional agriculture practices of terraces and acequias have facilitated the preservation of biophysical components (water flows and biological traits) upstream and, thereby, the supply of ecosystem services. On the contrary, in the eastern part of the watershed, the supply of ecosystem services is low and the social demand of traditional agriculture downstream is high (Fig. 4). These results show the relevant role of traditional practices in agriculture to promote soil and water conservation through the use of terraces and acequias, respectively (Iniesta-Arandia et al. 2015). The viability of this area therefore requires the maintenance of traditional agricultural practices that are adapted to the extreme semiarid conditions.

In terms of local governance practices, acequias do not function merely as water canals (Archambault and Ulibarri 2007). As Iniesta-Arandia et al. (2015) described, water infiltration in acequias contributes to the maintenance of broad leaf vegetation species and humid habitats for other species (Espín et al. 2010), promoting regulating services, such as microclimatic regulation 
and water-related ecosystem services (Pulido-Bosch and Ben Sbih 1995). In addition, local irrigation communities promote the maintenance of local practices and social capital (Rodríguez 2006, Waylen et al. 2010). However, this traditional system is threatened by two principal indirect drivers: (1) rural abandonment caused by depopulation and the conversion of the economy to the service sector (Pineda 2001) and (2) the intensification of agricultural systems, including the introduction of modern irrigation canals (Spalding 2000, Iniesta-Arandia et al. 2015). If the acequias system falls into disuse, the terraced agricultural system will suffer the same consequence, resulting in increased soil erosion(Douglas et al. 1994) or degradation of the stability of a particular terraceacequia-vegetation system (Spalding 2000). The current situation, in which this traditional irrigation system is advocated to be abandoned or modernized, could compromise the SESs' sustainability, i.e., the capacity to provide a diverse flow of ecosystem services to satisfy human needs while maintaining the management strategies and ecological processes underpinning services.

It is now acknowledged that in the Mediterranean, ecosystems have been sustained through a complex historical relationship between SES subsystems, where socio-cultural capital and traditional practices play an important role in natural capital conservation and the maintenance of a diverse flow of ecosystem services (Martín-López et al. 2012). In the Mediterranean region, ecosystems with differing degrees of extensive human management provide a greater diversity of ecosystem services compared with either pristine or intensified ecosystems (Bugalho et al. 2011, Willaarts et al. 2012). In this study, the geographical sectors (N2, A1, A2) with higher values for biophysical and local water governance factors were also characterized by diverse and lower social demands for ecosystem services (Fig. 3).

Our results suggest that ecosystem service trade-offs are determined by the joint operation of biophysical and sociocultural factors (Fig. 4) and, in turn, demonstrate that ecosystem services are coproduced by both ecosystems and social systems (Reyers et al. 2013). Similarly, the Intergovernmental Platform on Biodiversity and Ecosystem Services has recently recognized in its conceptual framework that ecosystem services are coproduced by nature and anthropogenic assets, i.e., biophysical and sociocultural factors, respectively (Díaz et al. 2015). Consequently, any attempt to manage SESs toward sustainability should identify the key functional factors (both biophysical and socio-cultural) that are essential for maintaining ecosystem service supply. However, the majority of studies on ecosystem service trade-offs only focus on associations between ecosystem services (Bennett et al. 2009). In this study, we take a step forward by assessing trade-offs between ecosystem services and between the factors that generate, or may influence, the supply and demand of ecosystem services, as well as their trade-offs. However, the analysis of associations between biophysical and socio-cultural factors, and between these factors and supply-supply and supply-demand trade-offs, entails high levels of complexity. Biophysical factors are usually measured in ecological units, whereas socio-cultural factors refer to administrative boundaries (Raudsepp-Hearne et al. 2010). This research used homogeneous geographical sectors and economic, demographic, social, resource-use, and land-use variables (for more details, see Iniesta-Arandia et al. 2011). Although the reduction of social-ecological complexity to homogeneous geographical sectors implies some loss in detailed information and data availability (and therefore limits to data analysis), it also facilitates spatial comparisons of interlinked components within SESs.

The management of SESs should consider ecosystem service trade-offs, as well as the biophysical and socio-cultural factors responsible for these trade-offs, to generate useful and suitable information for environmental planning and decision making. This study provides a quantitative analysis of the biophysical and socio-cultural factors underlying ecosystem service interactions through correlations to test linear associations (but not causalities) and the construction of flower diagrams to visualize spatial patterns. It also explores how these methods can provide the basis for studying trade-offs. Further research challenges include understanding trade-offs within a temporal context to compare temporal trends, application of additional methods to better examine spatially explicit variations, and the exploration of causalities between different management strategies and ecosystem service supply (Mouchet et al. 2014). Although there are several scientific challenges in ecosystem service trade-off research, conceptually this study advances knowledge through the demonstration of those biophysical and socio-cultural factors that coproduce and determining ecosystem services and tradeoffs in semiarid SESs (Fig. 1). Finally, our findings highlight the necessity of conducting social-ecological, place-based research for acquiring a comprehensive understanding of complex interrelationships within SESs that result in ecosystem service tradeoffs.

Responses to this article can be read online at: http://www.ecologyandsociety.org/issues/responses. $\mathrm{php} / 7785$

\section{Acknowledgments:}

The authors gratefully acknowledge the Sierra Nevada National and Natural Park staff and the Department of Environment of the Andalusian Government staff for providing the facilities to obtain data. We really appreciate the valuable comments made by $S$. Díaz and D. Cáceres on the first steps of the research. We thank I. Palomo for the cartographic work. We are grateful for the detailed comments provided by two anonymous reviewers. Funding for the development of this research was provided by a postdoctoral grant from the Spanish National Institute for Agriculture and Food Research and Technology (INIA), which is cofunded by the Social European Fund; the Seventh Framework Programme of the European Commission (FP7, 2007-2013) under the BESAFE project (Biodiversity and Ecosystem Services: Arguments for our Future Environment, Contract No. 282743; http://www. besafe-project. net); and the OpenNESS Project (Operationalisation of Natural capital and Ecosystem Services: From Concepts to Real-World Applications, Contract No. 308428).

\section{LITERATURE CITED}

Alba-Tercedor, J., P. Jáimez-Cuellar, M. Álvarez, J. Avilés, N. Bonada, J. Casas, A. Mellado, M. Ortega, I. Pardo, N. Prat, M. Rieradevall, S. Robles, C. E. Sáinz-Cantero, A. Sánchez-Ortega, 
M. L. Suárez, M. Toro, M. R. Vidal-Abarca, S. Vivas, and C. Zamora-Muñoz. 2002. Caracterización del estado ecológico de ríos mediterráneos ibéricos mediante el índice IBMWP (antes BMWP). Limnetica 21:175-186.

Alba-Tercedor, J., and A. Sánchez-Ortega. 1988. Un método rápido y simple para evaluar la calidad biológica de las aguas corrientes basado en el de Hellawell (1978). Limnetica 4:51-56.

Archambault, S., and J. Ulibarri. 2007. Nonmarket valuation of acequias: stakeholder analysis. Environmental Engineering and Management Journal 6:491-495.

Archaimbault, V., P. Usseglio-Polatera, J. Garric, J.-G. Wasson, and M. Babut. 2010. Assessing pollution of toxic sediment in streams using bio-ecological traits of benthic macroinvertebrates. Freshwater Biology 55:1430-1446. http://dx.doi.org/10.1111/ j.1365-2427.2009.02281.x

Armas, C., J. D. Miranda, F. M. Padilla, and F. I. Pugnaire. 2011. Special issue: the Iberian Southeast [preface]. Journal of Arid Environments 75:1241-1243. http://dx.doi.org/10.1016/j. jaridenv.2011.08.002

Aznar-Sánchez, J. A., E. Galdeano-Gómez, and J. C. Pérez-Mesa. 2011. Intensive horticulture in Almeria (Spain): a counterpoint to current European rural policy strategies. Journal of Agrarian Change 11:241-261. http://dx.doi.org/10.1111/j.1471-0366.2011.00301. $\underline{\mathrm{x}}$

Ban, N. C., M. Mills, J. Tam, C. C. Hicks, S. Klain, N. Stoeckl, M. C. Bottrill, J. Levine, R. L. Pressey, T. Satterfield, and K. M. A. Chan. 2013. A social-ecological approach to conservation planning: embedding social considerations. Frontiers in Ecology and the Environment 11:194-202. http://dx.doi.org/10.1890/110205

Bateman, I. J., A. R. Harwood, G. M. Mace, R. T. Watson, D. J. Abson, B. Andrews, A. Binner, A. Crowe, B. H. Day, S. Dugdale, C. Fezzi, J. Foden, D. Hadley, R. Haines-Young, M. Hulme, A. Kontoleon, A. A. Lovett, P. Munday, U. Pascual, J. Paterson, G. Perino, A. Sen, G. Siriwardena, D. van Soest, and M. Termansen. 2013. Bringing ecosystem services into economic decisionmaking: land use in the United Kingdom. Science 341:45-50. http://dx.doi.org/10.1126/science.1234379

Bennett, E. M., G. D. Peterson, and L. J. Gordon. 2009. Understanding relationships among multiple ecosystem services. Ecology Letters 12:1-11. http://dx.doi.org/10.1111/j.1461-0248.2009.01387. $\underline{\mathrm{X}}$

Brauman, K. A., G. C. Daily, T. K. Duarte, and H. A. Mooney. 2007. The nature and value of ecosystem services: an overview highlighting hydrologic services. Annual Review of Environment and Resources 32:67-98. http://dx.doi.org/10.1146/annurev. energy.32.031306.102758

Bugalho, M. N., M. C. Caldeira, J. S. Pereira, J. Aronson, and J. G. Pausas. 2011. Mediterranean cork oak savannas require human use to sustain biodiversity and ecosystem services. Frontiers in Ecology and the Environment 9:278-286. http://dx.doi. org/10.1890/100084

Butler, J. R. A., G. Y. Wong, D. J. Metcalfe, M. Honzák, P. L. Pert, N. Rao, M. E. van Grieken, T. Lawson, C. Bruce, F. J. Kroon, and J. E. Brodie. 2013. An analysis of trade-offs between multiple ecosystem services and stakeholders linked to land use and water quality management in the Great Barrier Reef, Australia. Agriculture, Ecosystems \& Environment 180:176-191. http://dx. doi.org/10.1016/j.agee.2011.08.017

Cano-Manuel, J. L. 2000. Las acequias de sierra Nevada. Informe técnico del Organismo Autónomo de Parques Nacionales. Parque Nacional de Sierra Nevada-Tragsa, Granada, Spain.

Cardinale, B. J., J. E. Duffy, A. Gonzalez, D. U. Hooper, C. Perrings, P. Venail, A. Narwani, G. M. Mace, D. Tilman, D. A. Wardle, A. P. Kinzig, G. C. Daily, M. Loreau, J. B. Grace, A. Larigauderie, D. S. Srivastava, and S. Naeem. 2012. Biodiversity loss and its impact on humanity. Nature 486:59-67. http://dx.doi. org/10.1038/nature 11148

Casanoves, F., L. Pla, J. A. Di Rienzo, and S. Díaz. 2011. FDiversity: a software package for the integrated analysis of functional diversity. Methods in Ecology and Evolution 2:233-237. http://dx.doi.org/10.1111/j.2041-210X.2010.00082.x

Castro, A. J., P. H. Verburg, B. Martín-López, M. GarcíaLlorente, J. Cabello, C. C. Vaughn, and E. López. 2014. Ecosystem service trade-offs from supply to social demand: a landscape-scale spatial analysis. Landscape and Urban Planning 132:102-110. http://dx.doi.org/10.1016/j.landurbplan.2014.08.009

Cheimonopoulou, M. T., D. C. Bobori, I. Theocharopoulos, and M. Lazaridou. 2011. Assessing ecological water quality with macroinvertebrates and fish: a case study from a small Mediterranean river. Environmental Management 47:279-290. http://dx.doi.org/10.1007/s00267-010-9598-8

Consejería de Agricultura Pesca y Medio Ambiente, Regional Ministry of Agriculture, Fisheries and Environment of the Government of Andalusia (CAPMA). 2010. Plan hidrológico de la demarcación hidrográfica de las Cuencas Mediterráneas Andaluzas. Junta de Andalucía y Fondo Europeo de Desarrollo Regional, Andalusia, Spain.

De Bello, F., S. Lavorel, S. Díaz, R. Harrington, J. H. C. Cornelissen, R. D. Bardgett, M. P. Berg, P. Cipriotti, C. K. Feld, D. Hering, P. Martins da Silva, S. G. Potts, L. Sandin, J. P. Sousa, J. Storkey, D. A. Wardle, and P. A. Harrison. 2010. Towards an assessment of multiple ecosystem processes and services via functional traits. Biodiversity and Conservation 19:2873-2893. http://dx.doi.org/10.1007/s10531-010-9850-9

Di Iacovo, F., R. Moruzzo, C. Rossignoli, and P. Scarpellini. 2014. Transition management and social innovation in rural areas: lessons from social farming. Journal of Agricultural Education and Extension 20:327-347. http://dx.doi.org/10.1080/1389224X.2014.887761

Díaz, S., S. Demissew, J. Carabias, C. Joly, M. Lonsdale, N. Ash, A. Larigauderie, J. Ram Adhikari, S. Arico, A. Báldi, A. Bartuska, I. A. Baste, A. Bilgin, E. Brondiizio, K. M. A. Chan, V. E. Figueroa, A. Duraiappah, M. Fischer, R. Hill, T. Koetz, P. Leadley, P. Lyver, G. Mace, B. Martín-López, M. Okumura, D. Pacheco, U. Pascual, E. Selvin Pérez, B. Reyers, E. Roth, O. Saito, R. J. Scholes, N. Sharma, H. Tallis, R. Thaman, R. Watson, T. Yahara, Z. Abdul Hamid, C. Akosim, Y. Al-Hafedh, R. Allahverdiyev, E. Amankwah, T. Stanley Asah, Z. Asfaw, G. Bartus, L. A. Brooks, J. Caillaux, G. Dalle, D. Darnaedi, A. Driver, G. Erpuls, P. Escobar-Eyzaguirre, P. Failler, A. M. 
Mokhtar Fouda, B. Fu, H. Gundimeda, S. Hashimoto, F. Homer, S. Lavorel, G. Lichtenstein, W. A. Mala, W. Mandivenyi, P. Matczak, C. Mbizvo, M. Mehrdadi, J. P. Metzger, J. B. Mikissa, H. Moller, H. A. Mooney, P. Mumby, H. Nagendra, C. Nesshover, A. A. Oteng-Yeboah, G. Pataky, M. Roué, J. Rubis, M. Schultz, P. Smith, R. Sumaila, K. Takeuchi, S. Thomas, M. Verma, Y. YeoChang, and D. Zlatanova. 2015. The IPBES Conceptual Framework - connecting nature and people. Current Opinion in Environmental Sustainability 14:1-16. http://dx.doi.org/10.1016/j. cosust.2014.11.002

Díaz, S., J. Fargione, F. S. Chapin, III, and D. Tilman. 2006. Biodiversity loss threatens human well-being. PLoS Biology 4:1300-1305. http://dx.doi.org/10.1371/journal.pbio.0040277

Díaz, S., S. Lavorel, F. S. Chapin, III, P. A. Tecco, D. Gurvich, and K. Grigulis. 2007. Functional diversity - at the crossroads between ecosystem functioning and environmental filters. Pages 81-91 in J. G. Canadell, D. E. Pataki, and L. F. Pitelka, editors. Terrestrial ecosystems in a changing world. Springer, Berlin, Germany. http://dx.doi.org/10.1007/978-3-540-32730-1_7

Douglas, T. D., S. J. Kirkby, R. W. Critchley, and G. J. Park. 1994. Agricultural terrace abandonment in the Alpujarra, Andalucía, Spain. Land Degradation \& Development 5:281-291. http://dx.doi. org/10.1002/ldr.3400050405

Downward, S. R., and R. Taylor. 2007. An assessment of Spain's Programa AGUA and its implications for sustainable water management in the province of Almeria, southeast Spain. Journal of Environmental Management 82:277-289. http://dx.doi. org/10.1016/j.jenvman.2005.12.015

Espín, R., E. Ortiz, and J. R. Guzmán. 2010. Manual del acequiero. Parques Nacional y Natural de Sierra Nevada, Agencia Andaluza del Agua. Consejería de Medio Ambiente. Junta de Andalucía, Granada, Spain.

Falkenmark, M., and J. Rockström. 2004. Balancing water for humans and nature. The new approach to ecohydrology, Earthscan, Bristol, UK.

Fernández-Escalante, A. E., M. García-Rodríguez, and F. Villarroya Gil. 2006. Las acequias de careo, un dispositivo pionero de recarga artificial de acuíferos en Sierra Nevada, España. Caracterización e inventario. Revista de Ciencia, Tecnología y Medio Ambiente IV. [online] URL: http://www.uax.es/ publicaciones/archivos/TECEOC06 001.pdf

García-Llorente, M., B. Martín-López, S. Díaz, and C. Montes. 2011. Can ecosystem properties be fully translated into service values? An economic valuation of aquatic plant services. Ecological Applications 21:3083-3103. http://dx.doi.org/10.1890/10-1744.1

García-Llorente, M., B. Martín-López, P. A. L. D. Nunes, A. J. Castro, and C. Montes. 2012. A choice experiment study for landuse scenarios in semi-arid watershed environments. Journal of Arid Environments 87:219-230. http://dx.doi.org/10.1016/j. jaridenv.2012.07.015

García-Ruiz, J. M., J. I. López-Moreno, S. M. Vicente-Serrano, T. Lasanta-Martínez, and S. Beguería. 2011. Mediterranean water resources in a global change scenario. Earth-Science Reviews 105:121-139. http://dx.doi.org/10.1016/j.earscirev.2011.01.006
Gordon, L. J., C. M. Finlayson, and M. Falkenmark. 2010. Managing water in agriculture for food production and other ecosystem services. Agricultural Water Management 97:512-519. http://dx.doi.org/10.1016/j.agwat.2009.03.017

Harrison, P. A., P. M. Berry, G. Simpson, J. R. Haslett, M. Blicharska, M. Bucur, R. Dunford, B. Egoh, M. Garcia-Llorente, N. Geamănă, W. Geertsema, E. Lommelen, L. Meiresonne, and F. Turkelboom. 2014. Linkages between biodiversity attributes and ecosystem services: a systematic review. Ecosystem Services 9:191-203. http://dx.doi.org/10.1016/i.ecoser.2014.05.006

Howe, C., H. Suich, B. Vira, and G. M. Mace. 2014. Creating winwins from trade-offs? Ecosystem services for human well-being: a meta-analysis of ecosystem service trade-offs and synergies in the real world. Global Environmental Change 28:263-275. http:// dx.doi.org/10.1016/j.gloenvcha.2014.07.005

Iniesta-Arandia, I., D. García del Amo, A. P. García-Nieto, C. Piñeiro, C. Montes, and B. Martín-López. 2015. Factors influencing local ecological knowledge maintenance in Mediterranean watersheds: insights for environmental policies. AMBIO 44:285-296. http://dx.doi.org/10.1007/s13280-014-0556-1

Iniesta-Arandia, I., M. García-Llorente, P. A. Aguilera, C. Montes, and B. Martín-López. 2014. Socio-cultural valuation of ecosystem services: uncovering the links between values, drivers of change, and human well-being. Ecological Economics 108:36-48. http://dx.doi.org/10.1016/j.ecolecon.2014.09.028

Iniesta-Arandia, I., M. García-Llorente, B. Martín-López, P. A. Aguilera, and C. Montes. 2011. La evaluación de los servicios de los ecosistemas: una aproximación socio-ecosistémica a la gestión de cuencas hidrográficas. VII Congreso Ibérico sobre Gestión y Planificación del Agua Ríos Ibéricos +10. Mirando al futuro tras 10 años de DMA. 16-19 February 2011, Talavera de la Reina, Spain. [online] URL: http://www.fnca.eu/images/documentos/ VII\%20C.IBERICO/Comunicaciones/A3/16-Iniesta.pdf

Laliberté, E., and P. Legendre. 2010. A distance-based framework for measuring functional diversity from multiple traits. Ecology 91:299-503. http://dx.doi.org/10.1890/08-2244.1

Laliberté, E., J. A. Wells, F. DeClerck, D. J. Metcalfe, C. P. Catterall, C. Queiroz, I. Aubin, S. P. Bonser, Y. Ding, J. M. Fraterrigo, S. McNamara, J. W. Morgan, D. S. Merlos, P. A. Vesk, and M. M. Mayfield. 2010. Land-use intensification reduces functional redundancy and response diversity in plant communities. Ecology Letters 13:76-86. http://dx.doi.org/10.1111/ j.1461-0248.2009.01403.X

Lavorel, S. 2013. Plant functional effects on ecosystem services. Journal of Ecology 101:4-8. http://dx.doi.org/10.1111/1365-2745.12031

Lavorel, S., and K. Grigulis. 2012. How fundamental plant functional trait relationships scale-up to trade-offs and synergies in ecosystem services. Journal of Ecology 100:128-140. http://dx. doi.org/10.1111/j.1365-2745.2011.01914.X

Liu, J.G., T. Dietz, S. R. Carpenter, M. Alberti, C. Folke, E. Moran, A. N. Pell, P. Deadman, T. Kratz, J. Lubchenco, E. Ostrom, Z. Ouyang, W. Provencher, C. L. Redman, S. H. Schneider, and W. W. Taylor. 2007. Complexity of coupled human and natural systems. Science 317:1513-1516. http://dx.doi. org/10.1126/science. 1144004 
Lorenzo-Lacruz, J., S. M. Vicente-Serrano, J. I. López-Moreno, E. Morán-Tejeda, and J. Zabalza. 2012. Recent trends in Iberian streamflows (1945-2005). Journal of Hydrology 414-415:463-475. http://dx.doi.org/10.1016/j.jhydrol.2011.11.023

Maass, A., and R. Anderson. 1978. And the desert shall rejoice: conflict, growth, and justice in arid environments, MIT Press, Cambridge, Massachusetts, USA.

Maass, J., P. Balvanera, A. Castillo, G. C. Daily, H. A. Mooney, P. Ehrlich, M. Quesada, A. Miranda, V. J. Jaramillo, F. GarcíaOliva, A. Martínez-Yrizar, H. Cotler, J. López-Blanco, A. PérezJiménez, A. Búrquez, C. Tinoco, G. Ceballos, L. Barraza, R. Ayala, and J. Sarukhán. 2005. Ecosystem services of tropical dry forests: insights from long-term ecological and social research on the Pacific Coast of Mexico. Ecology and Society 10(1): 17. [online] URL: http://www.ecologyandsociety.org/vol10/iss1/ $\underline{\operatorname{art17l}}$

Martín-López, B., I. Iniesta-Arandia, M. García-Llorente, I. Palomo, I. Casado-Arzuaga, D. García Del Amo, E. GómezBaggethun, E. Oteros-Rozas, I. Palacios-Agundez, B. Willaarts, J. A. González, F. Santos-Martín, M. Onaindia, C. A. LópezSantiago, and C. Montes. 2012. Uncovering ecosystem services bundles through social preferences. PLoS ONE 76:e38970. http:// dx.doi.org/10.1371/journal.pone.0038970

Martínez-Rodríguez, F. C. 2011. Estudio de la huella energética del abastecimiento urbano de agua de la provincia de Almería. Trabajo de investigación de Máster. Universidad de Almería, Almería, Spain.

McShane, T. O., P. D. Hirsch, T. C. Trung, A. N. Songorwa, A. Kinzig, B. Monteferri, D. Mutekanga, H. Van Thang, J. L. Dammert, M. Pulgar-Vidal, M. Welch-Devine, J. P. Brosius, P. Coppolillo, and S. O'Connor. 2011. Hard choices: making tradeoffs between biodiversity conservation and human well-being. Biological Conservation 144:966-972. http://dx.doi.org/10.1016/j. biocon.2010.04.038

Meinzen-Dick, R. 2007. Beyond panaceas in water institutions. Proceedings of the National Academy of Sciences of the United States of America 104:15200-15205. http://dx.doi.org/10.1073/ pnas.0702296104

Millennium Ecosystem Assessment (MA). 2005. Ecosystems and human well-being: synthesis. Island Press, Washington, D.C., USA.

Mitchell, M. G. E., E. M. Bennett, and A. Gonzalez. 2013. Linking landscape connectivity and ecosystem service provision: current knowledge and research gaps. Ecosystems 16:894-908. http://dx.doi.org/10.1007/s10021-013-9647-2

Mouchet, M. A., P. Lamarque, B. Martín-López, E. Crouzat, P. Gos, C. Byczek, and S. Lavorel. 2014. An interdisciplinary methodological guide for quantifying associations between ecosystem services. Global Environmental Change 28:298-308. http://dx.doi.org/10.1016/j.gloenvcha.2014.07.012

Munné, A., and N. Prat. 2004. Defining river types in a Mediterranean area: a methodology for the implementation of the EU Water Framework Directive. Environmental Management 34:711-729. http://dx.doi.org/10.1007/s00267-003-0098-y
National Ecosystem Assessment (Spanish NEA). 2014. Ecosystems and biodiversity for human well-being. Synthesis of the key findings. Biodiversity Foundation of the Spanish Ministry of Agriculture, Food and Environment, Madrid, Spain.

Instrucción de Planificación Hidrológica (IPH). 2008. Orden ARM/2656/2008. De 10 de septiembre, por la que se aprueba la instrucción de planificación hidrológica. BOE 229:38472-38582.

Ortega, M., J. Velasco, A. Millán, and C. Guerrero. 2004. An ecological integrity index for littoral wetlands in agricultural catchments of semiarid Mediterranean regions. Environmental Management 33:412-430. http://dx.doi.org/10.1007/s00267-003-3059-6

Ostrom, E. 2007. A diagnostic approach for going beyond panaceas. Proceedings of the National Academy of Sciences of the United States of America 104:15181-15187. http://dx.doi. org/10.1073/pnas.0702288104

Ostrom, E. 2009. A general framework for analyzing sustainability of social-ecological systems. Science 325:419-422. http://dx.doi.org/10.1126/science.1172133

Palomo, I., B. Martín-López, M. Potschin, R. Haines-Young, and C. Montes. 2013. National Parks, buffer zones and surrounding lands: mapping ecosystem services flows. Ecosystem Services 4:104-116. http://dx.doi.org/10.1016/j.ecoser.2012.09.001

Pineda, F. D. 2001. Intensification, rural abandonment and nature conservation in Spain. Pages 23-38 in R. G. H. Bunce, M. PérezSoba, B. S. Elbersen, M. J. Prados, E. Andersen, M. Bell, and P. J. A. M. Smeets, editors. Examples of European agri-environment schemes and livestock systems and their influence on Spanish cultural landscapes. Proceedings of a European workshop, Soto del Real, 13-15 July 2000. Alterra, Green World Research, Alterra, Wageningen, The Netherlands.

Power, A. G. 2010. Ecosystem services and agriculture: tradeoffs and synergies. Philosophical Transactions of the Royal Society B 365:2959-2971. http://dx.doi.org/10.1098/rstb.2010.0143

Pulido-Bosch, A., and Y. Ben Sbih. 1995. Centuries of artificial recharge on the southern edge of the Sierra Nevada (Granada, Spain). Environmental Geology 26:57-63. http://dx.doi.org/10.1007/ $\underline{\mathrm{BF} 00776033}$

Quijas, S., L. E. Jackson, M. Maass, B. Schmid, D. Raffaelli, and P. Balvanera. 2012. Plant diversity and generation of ecosystem services at the landscape scale: expert knowledge assessment. Journal of Applied Ecology 49:929-940. http://dx.doi.org/10.1111/ j.1365-2664.2012.02153.X

Quintas-Soriano, C., A. J. Castro, M. García-Llorente, J. Cabello, and H. Castro. 2014. From supply to social demand: a landscapescale analysis of the water regulation service. Landscape Ecology 29:1069-1082. http://dx.doi.org/10.1007/s10980-014-0032-0

Raudsepp-Hearne, C., G. D. Peterson, and E. M. Bennett. 2010. Ecosystem service bundles for analyzing tradeoffs in diverse landscapes. Proceedings of the National Academy of Sciences of the United States of America 107:5242-5247. http://dx.doi. org/10.1073/pnas.0907284107

Reyers, B, R. Biggs, G. S. Cumming, T. Elmqvist, A. P. Hejnowicz, and S. Polasky. 2013. Getting the measure of ecosystem services: a social-ecological approach. Frontiers in Ecology and the Environment 11:268-273. http://dx.doi.org/10.1890/120144 
Rodríguez, J. P., T. D. Beard, Jr., E. M. Bennett, G. S. Cumming, S. Cork, J. Agard, A. P. Dobson, and G. D. Peterson. 2006. Tradeoffs across space, time, and ecosystem services. Ecology and Society 11(1): 28. [online] URL: http://www.ecologyandsociety. org/vol11/iss1/art28/

Rodríguez, S. 2006. Acequias. Water sharing, sanctity, and place. School for Advanced Research Press, Santa Fe, New Mexico, USA.

Safriel, U., and Z. Adeel. 2005. Dryland systems. Chapter 22 in R. Hassan, R. J. Scholes, and N. Ash, editors. Ecosystems and human well-being: current state and trends. Volume 1. Island Press, London, UK.

Sánchez-Montoya, M. M., M. R. Vidal-Abarca, and M. L. Suarez. 2010. Comparing the sensitivity of diverse macroinvertebrate metrics to a multiple stressor gradient in Mediterranean streams and its influence on the assessment of ecological status. Ecological Indicators 10:896-904. http://dx.doi. org/10.1016/j.ecolind.2010.01.008

Sánchez-Picón, A., J. A. Aznar-Sánchez, and J. García-Latorre. 2011. Economic cycles and environmental crisis in arid southeastern Spain. A historical perspective. Journal of Arid Environments 75:1360-1367. http://dx.doi.org/10.1016/j. jaridenv.2010.12.014

Seppelt, R., C. F. Dormann, F. V. Eppink, S. Lautenbach, and S. Schmidt. 2011. A quantitative review of ecosystem service studies: approaches, shortcomings and the road ahead. Journal of Applied Ecology 48:630-636. http://dx.doi.org/10.1111/j.1365-2664.2010.01952. $\underline{\mathrm{X}}$

Shannon, C. E. 1948. A mathematical theory of communication. Bell System Technical Journal 27:379-423. http://dx.doi. org/10.1002/j.1538-7305.1948.tb01338.x

Spalding, R. 2000. Water management in the high Alpujarra, Granada province, Andalucía, Spain: prospects for sustainability. II Anglo Spanish Symposium on Rural Geography. University of Valladolid, Valladolid, Spain.

Usseglio-Polatera, P., M. Bournaud, P. Richoux, and H. Tachet. 2000. Biological and ecological traits of benthic freshwater macroinvertebrates: relationships and definition of groups with similar traits. Freshwater Biology 43:175-205. http://dx.doi. org/10.1046/j.1365-2427.2000.00535.X

Vandewalle, M., F. de Bello, M. P. Berg, T. Bolger, S. Dolédec, F. Dubs, C. K. Feld, R. Harrington, P. A. Harrison, S. Lavorel, P. Martins da Silva, M. Moretti, J. Niemelä, P. Santos, T. Sattler, J. P. Sousa, M. T. Sykes, A. J. Vanbergen, and B. A. Woodcock. 2010. Functional traits as indicators of biodiversity response to land use changes across ecosystems and organisms. Biodiversity and Conservation 19:2921-2947. http://dx.doi.org/10.1007/ s10531-010-9798-9

Vidal-Legaz, B., J. Martínez-Fernández, A. S. Picón, and F. I. Pugnaire. 2013. Trade-offs between maintenance of ecosystem services and socioeconomic development in rural mountainous communities in southern Spain: a dynamic simulation approach. Journal of Environmental Management 131:280-297. http://dx. doi.org/10.1016/j.jenvman.2013.09.036
Waylen, K. A., A. Fischer, P. J. K. McGowan, S. J. Thirgood, and E. J. Milner-Gulland. 2010. Effect of local cultural context on the success of community-based conservation interventions. Conservation Biology 24:1119-1129. http://dx.doi.org/10.1111/ j.1523-1739.2010.01446.x

Willaarts, B. A., M. Volk, and P. A. Aguilera. 2012. Assessing the ecosystem services supplied by freshwater flows in Mediterranean agroecosystems. Agricultural Water Management 105:21-31. http://dx.doi.org/10.1016/j.agwat.2011.12.019

Williams, D. D. 2005. The biology of temporary waters. Oxford University Press, New York, New York, USA. http://dx.doi. org/10.1093/acprof:oso/9780198528128.001.0001 
1 Appendix 1. Biological factors.

2 Macroinvertebrates were collected following the multimetric Iberian Biomonitoring Working 3 Party (IBMWP) protocol. At each sample point, $100 \mathrm{~m}$ longitudinal meters were sampled in 20 4 kicks, and care was taken to represent all different habitats (rocks, detritus, shoreline, sand, and 5 fine sediments) at the sampling site. The substratum upstream of the kick-net $(250 \mu \mathrm{m})$ was 6 disturbed, and effort proportional to the relative importance of each habitat was expended to 7 sample all microhabitats present at the site (multi-habitat sampling). All collected material was 8 transferred into plastic containers and preserved in 96\% ethanol. Samples were then examined 9 under a stereoscope in the laboratory. Most animals were identified at the genus level. Riparian 10 vegetation was sampled following the criteria set out in the LEDA traitbase (Kleyer et al. 11 2008). At each sample point, transects $25 \mathrm{~m}$ long and $2.5 \mathrm{~m}$ wide were sampled from both 12 sides of the river. The total surface sample in each pint was $50 \mathrm{~m} \times 5 \mathrm{~m}$. Each individual found 13 was sampled and identified in the laboratory. 

objective of having represented each of the geographical sectors in the Nacimiento $(\mathrm{N})$ and

17 Adra (A) watersheds but avoiding when possible very close sites in order to obtain the higher

18 representation within each sector. Sites were also selected to be representative of the river

19 course and considering adequate access facilitated by overland roads. Macroinvert: macroinvertebrates.

\begin{tabular}{|c|c|c|}
\hline $\begin{array}{l}\text { Sample } \\
\text { point }\end{array}$ & $\begin{array}{l}\text { UTM coord. } \\
\text { (municipality) }\end{array}$ & $\begin{array}{l}\text { Prese } \\
\text { freshy }\end{array}$ \\
\hline \multicolumn{3}{|l|}{$\begin{array}{l}\text { Nacimiento } \\
\text { watershed }\end{array}$} \\
\hline 0 & $\begin{array}{l}501237 \\
4106096 \\
\text { (Hueneja) }\end{array}$ & Yes \\
\hline 1 & $\begin{array}{l}507555 \\
4129945 \\
\text { (Valle de } \\
\text { Zalabi) }\end{array}$ & Yes \\
\hline 2 & $\begin{array}{l}507223 \\
4117735 \\
\text { (Valle de } \\
\text { Zalabi) }\end{array}$ & No \\
\hline 3 & $\begin{array}{l}507935 \\
4117260 \\
\text { (Valle de } \\
\text { Zalabi) }\end{array}$ & No \\
\hline 4 & $\begin{array}{l}507460 \\
4108614 \\
\text { (Fiñana) }\end{array}$ & Yes \\
\hline 5 & $\begin{array}{l}511451 \\
4110990 \\
\text { (Fiñana) }\end{array}$ & No \\
\hline 6 & $\begin{array}{l}522662 \\
4120111 \\
\text { (Tres Villas) }\end{array}$ & No \\
\hline 7 & $\begin{array}{l}518719 \\
4117118 \\
\text { (Abrucena) }\end{array}$ & Yes \\
\hline 8 & $\begin{array}{l}516676 \\
4108329 \\
\text { (Abrucena) }\end{array}$ & Yes \\
\hline 9 & $\begin{array}{l}518434 \\
4111940 \\
\text { (Abrucena) }\end{array}$ & Yes \\
\hline 10 & $\begin{array}{l}522282 \\
4111417 \\
\text { (Abla) }\end{array}$ & No \\
\hline 11 & $\begin{array}{l}528981 \\
4115598 \\
\text { (Nacimiento) }\end{array}$ & No \\
\hline
\end{tabular}

High water flow, predominant habitat of rocks and vegetated shorelines, dominated by trees and shrubs (Populus spp. and Salix spp.). Type 12:

Mediterranean calcareous mountain river.

Water flow is very low. Populus alba is the dominant plant species, and there is abundant leaf litter in river. Type 12: Mediterranean calcareous mountain river.

River bed is dry and there are no signs of recent water flow. Riparian vegetation is poor and dominated by Retama sphaerocarpa. Type 12: Mediterranean calcareous mountain river.

River bed is dry and there are no signs of recent water flow. Riparian vegetation is poor and dominated by Retama sphaerocarpa. Type 12: Mediterranean calcareous mountain river.

High water flow. Canopy is dominated by Castanea sativa and Populus alba. Type 11: Mediterranean siliceous mountain river.

No water flow. Pinus sylvestris and Quercus tundifolia are abundant in the riparian community. zpe 11: Mediterranean siliceous mountain river.

No water flow during the sampling period. Riparian vegetation is scarce and dominated by Mediterranean shrubs (mainly Stipa tenacissima). Type 09:

Mineralised Mediterranean mountain river.

Water flow is very low. Riparian vegetation is dominated by Rubus ulmifolius and Thypha latifolia. Type 09: Mineralised Mediterranean mountain river. High water flow. The dominant species are Scirpus holoschoenus and Retama sphaerocarpa. Type 11: Mediterranean siliceous mountain river No water flow, only some pools along the river. Tamarix canariensis is the most abundant plant. Type 09: Mineralised Mediterranean mountain river.

No water flow. The herbaceous community is highly diverse. Tamarix canariensis is the most abundant shrub. Type 09: Mineralised Mediterranean mountain river.

No water during sampling period. Euphorbia segetalis, Dittrichia viscosa and Scirpus holoschoenus are the most abundant plant species. Type 09: Mineralised Mediterranean mountain river.
Organisms sampled

Riparian vegetation Macroinvert.

Riparian vegetation Macroinvert.

Riparian vegetation

Riparian vegetation

Riparian vegetation Macroinvert. Riparian vegetation

Riparian vegetation

Riparian vegetation Macroinvert. Riparian vegetation Macroinvert. Riparian vegetation Macroinvert Riparian vegetation

Riparian vegetation 


\begin{tabular}{|c|c|c|}
\hline 0 & $\begin{array}{l}491077 \\
4102997 \\
\text { (Válor) }\end{array}$ & Yes \\
\hline 1 & $\begin{array}{l}497998 \\
4106969 \\
\text { (Bayárcal) }\end{array}$ & Yes \\
\hline 2 & $\begin{array}{l}498840 \\
4102877 \\
\text { (Bayárcal) }\end{array}$ & Yes \\
\hline 3 & $\begin{array}{l}500826 \\
4102034 \\
\text { (Bayárcal) }\end{array}$ & No \\
\hline 4 & $\begin{array}{l}501849 \\
4096377 \\
\text { (Bayárcal) }\end{array}$ & No \\
\hline 5 & $\begin{array}{l}502632 \\
4092285 \\
\text { (Alcolea) }\end{array}$ & Yes \\
\hline 6 & $\begin{array}{l}493665 \\
4091322 \\
\text { (Ugíjar) }\end{array}$ & Yes \\
\hline 7 & $\begin{array}{l}489030 \\
4087049 \\
\text { (Ugíjar) }\end{array}$ & No \\
\hline 8 & $\begin{array}{l}497456 \\
4082054 \\
\text { (Berja) }\end{array}$ & No \\
\hline 9 & $\begin{array}{l}503595 \\
4089095 \\
\text { (Alcolea) }\end{array}$ & No \\
\hline 10 & $\begin{array}{l}505641 \\
4080128 \\
\text { (Berja) }\end{array}$ & No \\
\hline 11 & $\begin{array}{l}504798 \\
4086324 \\
\text { (Alcolea) }\end{array}$ & No \\
\hline
\end{tabular}

Water flow is very high. There are several trees species, predominantly Pinus and Populus. Type 11: Mediterranean siliceous mountain river.

Significant water flow, abundant leaf litter in the river bed. Riparian vegetation is dominated by herbaceous species (Geranium, Bromus). Type 11: Mediterranean siliceous mountain river.

No water flow, only some pools along the river, with abundant detritus. Rubus, Populus and Dryopteris are dominant. Type 11: Mediterranean siliceous mountain river.

No water during sampling period. Dryopteris filixmas and Rubus ulmifolius are the predominant species. Trees are abundant, including Populus, Quercus, Crataegus and Salix. Type 11:

Mediterranean siliceous mountain river.

No water flow. Euphorbia, Retama, and Rubus are predominant in the riparian ecosystem. Type 09:

Mineralised Mediterranean mountain river.

High water flow. Riparian community is dominated by Hordeum, Polypogon, Scirpus, Populus and Rhamnus. Type 09: Mineralised Mediterranean mountain river.

High water flow with abundant rocks. Genista,

Hordeum, Plantago and Scirpus are abundant in the riparian zone. Type 09: Mineralised Mediterranean mountain river.

No water flow. High biodiversity in the shrub community, with Tamarix, Avena, Genista and Salix predominant in the riparian zone. Type 09:

Mineralised Mediterranean mountain river.

No water flow. Tamarix and Avena are predominant. The invasive exotic species Acacia saligna was found. Type 07: Mineralised Mediterranean lowland river.

No water flow. Riparian community is dominated by herbaceous species (Hordeum, Avena, etc.). Type 07: Mineralised Mediterranean lowland river.

No water flow. No trees, only shrubs and herbaceous species. Verbascum nevadense was found (endemism). Type 07: Mineralised Mediterranean lowland river.

No water flow. Eruca and Stipa are predominant. Type 07: Mineralised Mediterranean lowland river.
Macroinvert. Riparian vegetation

Macroinvert. Riparian vegetation

Macroinvert. Riparian vegetation

Riparian vegetation

Riparian vegetation

Macroinvert. Riparian vegetation

Macroinvert. Riparian vegetation

Riparian vegetation

Riparian vegetation

Riparian vegetation

Riparian vegetation

Riparian vegetation 
21 Table A1.2. List of traits and their subdivision into attributes used to calculate the riparian vegetation functional dispersion index (FDis veg). Species abundance was used as weigthting variable. Abundance was estimated as follows: 1) rare, isolated individuals; 2) occasional, 1 $10 \%$ of species; 3 ) frequent, $10-50 \%$ of species; 4) abundant, $50-70 \%$ of species; and 5)

25 dominant, > 70\%. Gower dissimilarity matrix between all species using traits was also computed because it allows mixed variable types (continuous, categorical and binary).

\begin{tabular}{|c|c|c|}
\hline Trait & Attributes & Type \\
\hline Growth form & $\begin{array}{l}\text { Geophytes (cryptophyte resting in dry ground) } \\
(0=\text { non geophyte; } 1=\text { geophyte) } \\
\text { Phanerophytes (projecting into the air on stems -normally woody } \\
\text { perennials-with resting buds more than } 50 \mathrm{~cm} \text { above soil level) } \\
\text { ( } 0=\text { non phanerophyte; } 1=\text { phanerophyte) } \\
\text { Hemicryptophytes (buds at or near the soil surface) } \\
(0=\text { non hemicryptophytes; } 1=\text { hemicryptophytes) } \\
\text { Helophyte (cryptophyte resting in marshy ground) } \\
(0=\text { non helophyte; } 1=\text { helophyte) } \\
\text { Therophytes (annual plants which survive the unfavorable season in } \\
\text { the form of seeds and complete their life-cycle druing favorable } \\
\text { seasons) } \\
(0=\text { non therophyte; } 1=\text { therophyte) } \\
\text { Chamaephytes (projecting into the air on stems -normally woody } \\
\text { perennials-with resting buds between } 25-50 \mathrm{~cm} \text { above soil level) } \\
(0=\text { non chamaephytes; } 1=\text { chamaephytes })\end{array}$ & Binary \\
\hline Life span & $\begin{array}{l}\text { Perennial } \\
(0=\text { non perennial; } 1=\text { perennial }) \\
\text { Annual } \\
(0=\text { non annual; } 1=\text { annual }) \\
\text { Biannual } \\
(0=\text { non biannual; } 1=\text { biannual }) \\
\text { Semi-deciduous } \\
(0=\text { non semi-deciduous; } 1=\text { semi-deciduous }) \\
\text { Deciduous } \\
(0=\text { non deciduous; } 1=\text { deciduous })\end{array}$ & Binary \\
\hline Plant height & Average plant height $(\mathrm{mm})$ & Continuous \\
\hline Body flexibility & $\begin{array}{l}\text { Capacity of body to bend without breaking }\left(1=\text { flexing angle }<45^{\circ} \text {; }\right. \\
\left.2=45^{\circ}-300^{\circ} ; 3>300^{\circ}\right)\end{array}$ & Categorical \\
\hline Early phenology & $\begin{array}{l}\text { Growth mostly before the drought period (June-September) } \\
(0=\text { April-September; } 1=\text { before April) }\end{array}$ & Binary \\
\hline Vertical shoot architecture & $\begin{array}{l}\text { Single apical meristem } \\
(0=\text { no; } 1=\text { yes }) \\
\text { Multiple apical meristems } \\
(0=\text { no; } 1=\text { yes })\end{array}$ & $\begin{array}{l}\text { Binary } \\
\text { Binary }\end{array}$ \\
\hline Specific leaf area (SLA) & Average specific leaf area $\left(\mathrm{mm}^{2} / \mathrm{mg}\right)$ & Continuous \\
\hline Leaf texture & Leaf texture $(1=$ soft; $0=$ tough $)$ & Binary \\
\hline Physical defenses on stems & $\begin{array}{l}\text { Presence of spines or spine-like, hairy structures on stems } \\
(0=\text { non physical defenses on stems, } 1=\text { with physical defenses on } \\
\text { stems })\end{array}$ & Binary \\
\hline Physical defenses on leaves & $\begin{array}{l}\text { Presence of spines or spine-like, hairy structures on leaves } \\
(0=\text { non physical defenses on leaves, } 1=\text { with physical defenses on } \\
\text { leaves })\end{array}$ & Binary \\
\hline $\begin{array}{l}\text { Root and underground } \\
\text { structures }\end{array}$ & $\begin{array}{l}\text { Simple root } \\
(0=\text { non simple root; } 1=\text { simple root }) \\
\text { Stolons } \\
(0=\text { non stolons; } 1=\text { stolons })\end{array}$ & Binary \\
\hline
\end{tabular}


Rhizomes

$(0=$ non rhizomes $; 1=$ rhizomes $)$

Tubers

$(0=$ non tubers $; 1=$ tubers $)$

Dispersal mode

Autochory

Binary

( $0=$ non autochory; $1=$ autochory $)$

Wind dispersal

$(0=$ non wind dispersal; $1=$ wind dispersal $)$

Water dispersal

$(0=$ non water dispersal; $1=$ water dispersal $)$

Animal dispersal

$(0=$ non animal dispersal; $1=$ water dispersal $)$ 
29 Table A1.3. List of traits and their subdivision into attributes used to calculate the 30 macroinvertebrates functional dispersion index (FDis macro). Species abundance (in \%) was 31 used as weighting variable. Gower dissimilarity matrix between all species using traits was 32 also computed because it allows mixed variable types (continuous, categorical and binary).

\begin{tabular}{|c|c|c|}
\hline Trait & Attributes & Type \\
\hline Maximal size & $\begin{array}{l}\mathrm{mm} \\
\text { Trait } \log _{10} \text { transformed for the analysis }\end{array}$ & Continuos \\
\hline Life-cycle duration & $3=>1$ year; $2=1$ year, $1=<1$ year & Categorical \\
\hline $\begin{array}{l}\text { Potential no. Reproductive } \\
\text { cycles per year }\end{array}$ & $\begin{array}{l}3=>1 \text { cycle per year; } 2=1 \text { cycle per year } r, 1= \\
<1 \text { cycle per year }\end{array}$ & Categorical \\
\hline Aquatic stage & $\begin{array}{l}\text { Egg } \\
(0=\text { non egg; } 1=\text { egg }) \\
\text { Larva } \\
(0=\text { non larva; } 1=\text { larva }) \\
\text { Pupa } \\
(0=\text { non pupa; } 1=\text { pupa }) \\
\text { Adult } \\
(0=\text { non adult; } 1=\text { adult })\end{array}$ & Binary \\
\hline Reproduction & $\begin{array}{l}\text { Ovoviviparity } \\
(0=\text { non ovoviviparity; } 1=\text { ovoviviparity) } \\
\text { Isolated eggs } \\
(0=\text { non egg; } 1=\text { egg }) \\
\text { Clutches } \\
(0=\text { non clutches; } 1=\text { clutches })\end{array}$ & Binary \\
\hline Dissemination & $\begin{array}{l}\text { Aquatic passive } \\
(0=\text { non aquatic passive; } 1=\text { aquatic passive }) \\
\text { Aquatic active } \\
(0=\text { non aquatic active; } 1=\text { aquatic active }) \\
\text { Aerial passive } \\
(0=\text { non aerial passive; } 1=\text { aerial passive }) \\
\text { Aerial active } \\
(0=\text { non aerial active; } 1=\text { aerial active })\end{array}$ & Binary \\
\hline Resistance form & Yes $(=1)$, None $(=0)$ & Binary \\
\hline Respiration & $\begin{array}{l}\text { Tegument } \\
(0=\text { non tegument; } 1=\text { tegument }) \\
\text { Gill } \\
(0=\text { non gill; } 1=\text { gill }) \\
\text { Plastrom } \\
(0=\text { non plastrom; } 1=\text { plastrom }) \\
\text { Spiracle (aerial) } \\
(0=\text { non spiracle; } 1=\text { spiracle }\end{array}$ & Binary \\
\hline Food type & $\begin{array}{l}\text { Plant detritus } \\
(0=\text { non plant detritus; } 1=\text { plant detritus }) \\
\text { Living microphytes } \\
(0=\text { non living microphytes; } 1=\text { living } \\
\text { microphytes }) \\
\text { Living macrophytes } \\
(0=\text { non living macrophytes; } 1=\text { living } \\
\text { macrophytes }) \\
\text { Dead animal } \\
(0=\text { non dead animal; } 1=\text { dead animal }) \\
\text { Living microinvertebrates } \\
(0=\text { non living microinvertebrates; } 1=\text { living } \\
\text { microinvertebrates }) \\
\text { Living macroinvertebrates } \\
(0=\text { non living macroinvertebrates; } 1=\text { living }\end{array}$ & Binary \\
\hline
\end{tabular}




\begin{tabular}{|c|c|c|}
\hline & $\begin{array}{l}\text { macroinvertebrates }) \\
\text { Vertebrates } \\
(0=\text { non vertebrates; } 1=\text { vertebrates })\end{array}$ & \\
\hline \multirow[t]{8}{*}{ Feeding habits } & $\begin{array}{l}\text { Absorber } \\
(0=\text { non absorber; } 1=\text { absorber })\end{array}$ & Binary \\
\hline & $\begin{array}{l}\text { Shredder } \\
(0=\text { non shredder; } 1=\text { shredder })\end{array}$ & \\
\hline & Scraper & \\
\hline & $(0=$ non scraper $; 1=$ scraper $)$ & \\
\hline & Filter feeder & \\
\hline & $(0=$ non filter feeder; $1=$ filter feeder $)$ & \\
\hline & Predator & \\
\hline & $(0=$ no predator, $1=$ predator $)$ & \\
\hline \multirow{8}{*}{$\begin{array}{l}\text { Locomotion and sustratum } \\
\text { relation }\end{array}$} & Burrower (epibenthic) & Binary \\
\hline & $(0=$ non burrower; $1=$ burrower $)$ & \\
\hline & Temporarily attached & \\
\hline & $\begin{array}{l}(0=\text { temporarily attached; } 1=\text { temporarily } \\
\text { attached })\end{array}$ & \\
\hline & Swimmer & \\
\hline & $(0=$ non swimmer; $1=$ swimmer $)$ & \\
\hline & Crawler & \\
\hline & $(0=$ non crawler $; 1=$ crawler $)$ & \\
\hline
\end{tabular}

Kleyer, M., R. M. Bekker, I. C. Knevel, J. P. Bakker, K. Thompson, M. Sonnenschein, P.

37 Poschlod, J. M. Van Groenendael, L. Klimeš, J. Klimešová, S. Klotz, G. M. Rusch, M. Hermy,

38 D. Adriaens, G. Boedeltje, B. Bossuyt, A. Dannemann, P. Endels, L. Götzenberger, J. G.

39 Hodgson, A. K. Jackel, I. Kühn, D. Kunzmann, W. A. Ozinga, C. Römermann, M. Stadler, J.

40 Schlegelmilch, H. J. Steendam, O. Tackenberg, B. Wilmann, J. H. C. Cornelissen, O. Eriksson,

41 E. Garnier, and B. Peco. 2008. The LEDA Traitbase: a database of life-history traits of the

42 Northwest European flora. Journal of Ecology 96:1266-1274. 
1 Appendix 2. Social demand for ecosystem services.

2 Questionnaire structure and content (for the full version see Iniesta-Arandia et al. 2014).

3 I. Respondent's relationship with the study area (e.g. Hometown, visited areas, main reason of being 4 in the area, family origin).

5 II. Perception of the importance and vulnerability of benefits*:

6 From the lists panel of benefits provided by the watersheds (see Table A3.1), could you choose 74 that, in your opinion, are the most important in the area for social well-being?

\begin{tabular}{|l|}
\hline Benefit \\
\hline \\
\hline \\
\hline
\end{tabular}

9 III. Indicators of human well-being (i.e. based on agreement with statements about the life in 10 their town).

11 IV. Future options based on the influence of drivers of change (i.e. based on aspects that in 12 their opinion are important or have an influence in the future of the area).

13 V. Respondents' general environmental behavior (e.g. membership of any association, visited 14 protected areas, consumption of organic food).

15 VI. Socio-economic variables (e.g. Level of formal education, age, profession, net monthly 16 income).

\footnotetext{
${ }^{*}$ We used the term benefits instead of ecosystem services to avoid technical terms and prevent educational and cultural biases.
} 

conducted.

\begin{tabular}{|c|c|c|}
\hline Category & Sub-category & Example in semiarid watersheds \\
\hline \multirow[t]{9}{*}{ Provisioning } & $\begin{array}{l}\text { Traditional } \\
\text { agriculture }\end{array}$ & Olive tree, almond three, vine, cereal, fruit orchard \\
\hline & Intensive agriculture & $\begin{array}{l}\text { Pepper, tomato, green bean, melon, watermelon, } \\
\text { courgette }\end{array}$ \\
\hline & $\begin{array}{l}\text { Shepherding and/or } \\
\text { livestock }\end{array}$ & Sheep, goat, cow \\
\hline & Forest harvesting & Mushrooms, berries, and acorns \\
\hline & Fibre harvesting & Tussock-grass (e.g. Stipa tenacissima) \\
\hline & Freshwater & Agriculture and human consumption \\
\hline & Clean energy & Wind power and solar energy \\
\hline & Timber & Holm oak, olive tree and pine wood \\
\hline & Apiculture & Honey \\
\hline \multirow[t]{7}{*}{ Regulating } & Air quality & Air purification through vegetation \\
\hline & $\begin{array}{l}\text { Microclimate } \\
\text { regulation }\end{array}$ & $\begin{array}{l}\mathrm{CO}_{2} \text { sequestration and rain processes control through } \\
\text { vegetation }\end{array}$ \\
\hline & Habitat for species & $\begin{array}{l}\text { Natural protected areas such as the Albuferas del Adra } \\
\text { (White-headed duck; Oxyura leucocephala) }\end{array}$ \\
\hline & Water regulation & Riparian vegetation, water infiltrations \\
\hline & Water quality & Water purification \\
\hline & $\begin{array}{l}\text { Erosion control and } \\
\text { soil protection }\end{array}$ & Terraces, deforestation \\
\hline & Soil fertility & Water courses and riversides \\
\hline \multirow[t]{8}{*}{ Cultural } & $\begin{array}{l}\text { Satisfaction of } \\
\text { conserving species } \\
\text { (existence) }\end{array}$ & $\begin{array}{l}\text { Satisfaction for species conservation (e.g. fartet - } \\
\text { Aphanius iberus- or wild goat -Capra pyrenaica-) }\end{array}$ \\
\hline & Relaxation & Water, snow and mountainous landscapes \\
\hline & $\begin{array}{l}\text { Local ecological } \\
\text { knowledge }\end{array}$ & $\begin{array}{l}\text { Traditional water management, ethnographic museums, } \\
\text { agriculture in terraces, basketwork }\end{array}$ \\
\hline & $\begin{array}{l}\text { Environmental } \\
\text { education }\end{array}$ & $\begin{array}{l}\text { Books and activities about the environment and } \\
\text { traditions in the study area }\end{array}$ \\
\hline & Recreational hunting & $\begin{array}{l}\text { Small game and big game hunting (e.g., rabbit, } \\
\text { partridge, wild boar and goat) }\end{array}$ \\
\hline & Ecotourism & $\begin{array}{l}\text { Hiking, horse riding, mountain activities in the } \\
\text { protected area and surroundings, including rural and } \\
\text { agro-tourism }\end{array}$ \\
\hline & Aesthetic values & Beautiful landscapes such as mountains with snow \\
\hline & Local identity & Feel a special bond with the Alpujarra region \\
\hline
\end{tabular}


24 change and human well-being. Ecological Economics 108: 36-48.

25 
1 Appendix 3. Maps of blue and green freshwater flows in the (A) Nacimiento and (B) Adra 2 watersheds.

3 (A)
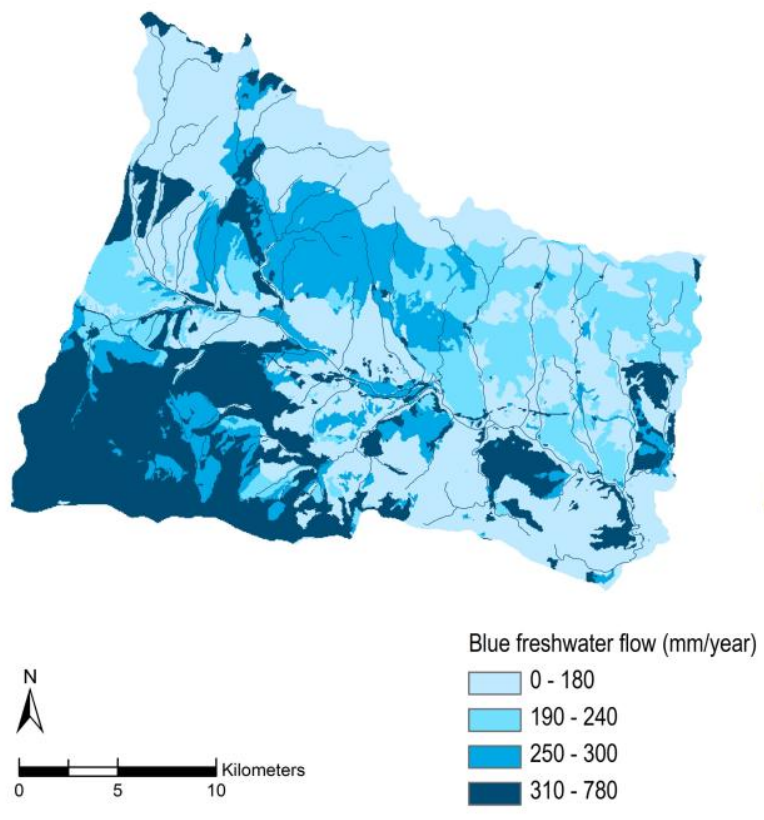

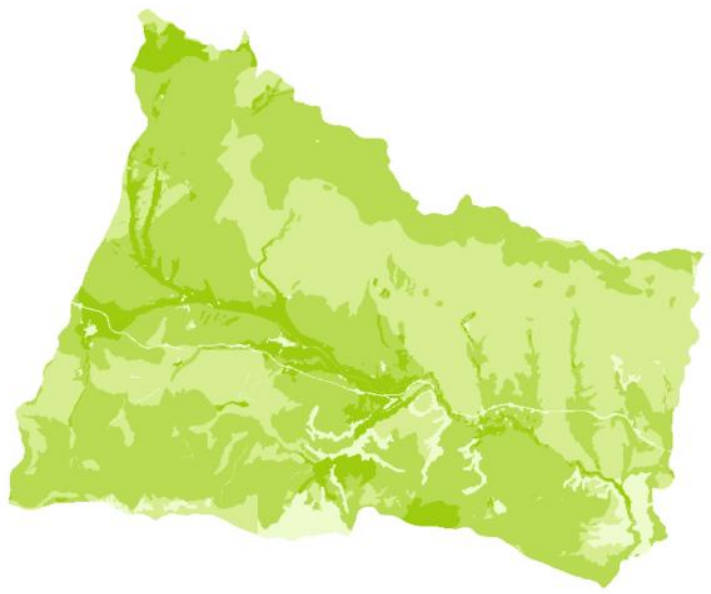

Green freshwater flow (mm/year)

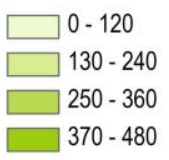

4

(B)
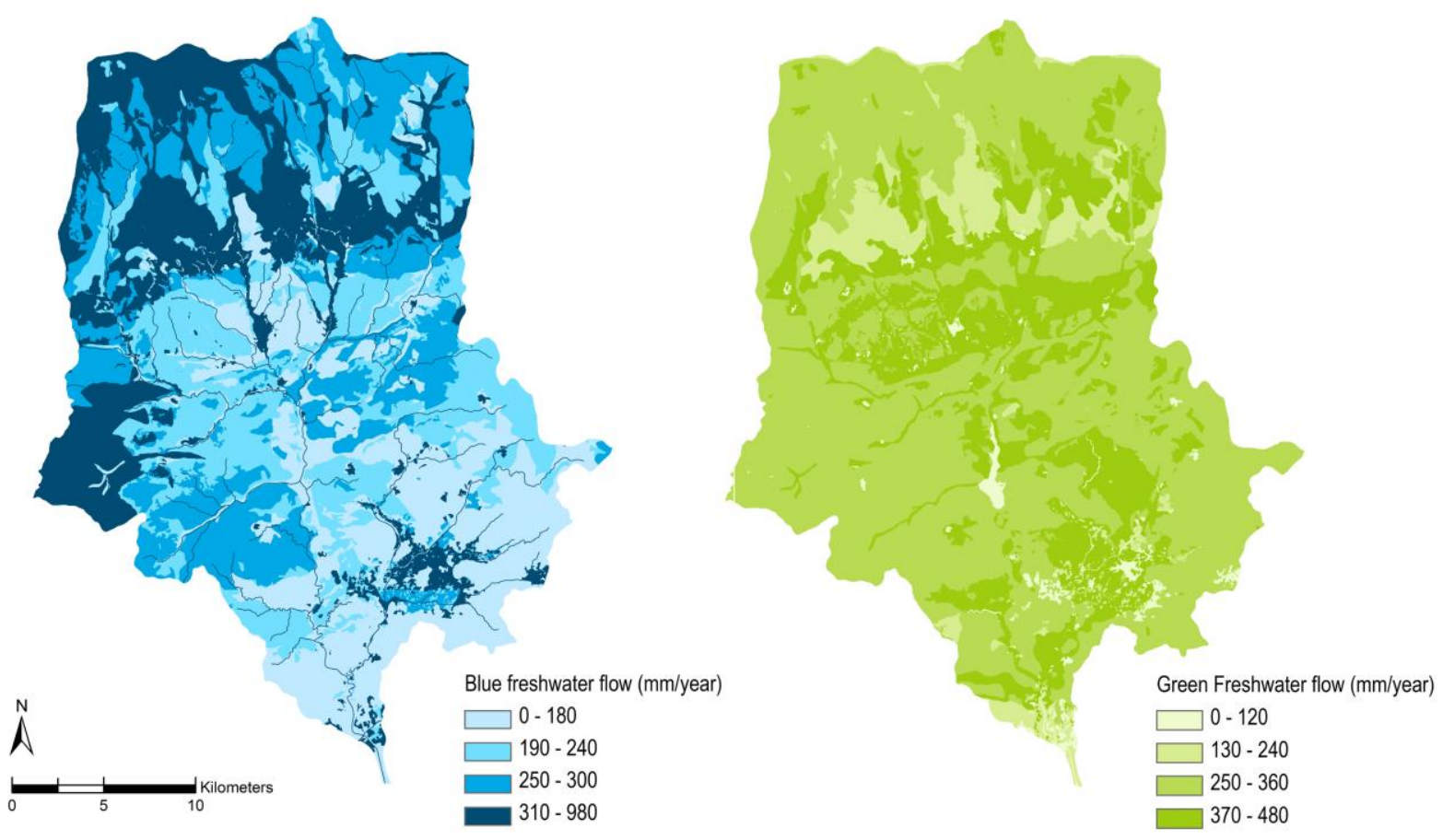